\title{
The European Union, the Euro, and Equity Market Integration
}

\author{
Geert Bekaert \\ Columbia University, New York, NY 10027 USA \\ National Bureau of Economic Research, Cambridge, MA 02138 USA \\ Campbell R. Harvey \\ Duke University, Durham, NC 27708 USA \\ National Bureau of Economic Research, Cambridge, MA 02138 USA \\ Christian T. Lundblad \\ University of North Carolina, Chapel Hill, NC 27599 USA \\ Stephan Siegel* \\ University of Washington, Seattle, WA 98195 USA
}

October 2012

\footnotetext{
${ }^{*}$ The paper has benefitted from the comments of participants at presentations at the Oxford-Man Institute, Tilburg University, University of Amsterdam, University of Washington, the Heterogeneous Nations and Globalized Financial Markets Conference at the National Bank of Poland, the Italian Ministry of Economics and Finance, the 2011 Society for Economic Dynamics Conference in Ghent, Belgium, the 10th Annual Darden International Finance Conference, the 2011 German Finance Association Meetings, the University of Maryland, the 2012 American Finance Association Conference, the 2012 Western Finance Association Conference, Singapore Management University, and the National University of Singapore. We would also like to acknowledge Michael Melvin, Stijn Van Nieuwerburgh, and the referee for very helpful comments. Lundblad acknowledges support from the European Commission's grant to the European Union Center of Excellence at the University of North Carolina at Chapel Hill. Siegel acknowledges generous research funding from the Global Business Center at the University of Washington. Send correspondence to: Campbell R. Harvey, Fuqua School of Business, Duke University, Durham, NC 27708. Phone: +1 919.660.7768, E-mail: cam.harvey@duke.edu .
} 


\title{
The European Union, the Euro, and Equity Market Integration
}

\begin{abstract}
We use industry valuation differentials across European countries to study the impact of membership in the European Union as well as the Eurozone on both economic and financial integration. In integrated markets, discount rates and expected growth opportunities should be similar within one industry, irrespective of the country, implying narrowing valuation differentials as countries become more integrated. Our analysis of the 1990 to 2007 period shows that membership in the EU significantly lowered discount rate and expected earnings growth differentials across countries. In contrast, the adoption of the Euro was not associated with increased integration. Our results do not change when the sample is extended to include the recent crisis period.
\end{abstract}




\section{Introduction}

No region in the world has done more to integrate its economies than the European countries, where the European Union (EU, henceforth) set out after World War II to free the movement of goods and services, capital, and labor. As a result, financial economists have examined the extent of European debt and equity market integration before the onset of the recent financial crisis [see Baele, Ferrando, Hordahl, Krylova and Monnet (2004) for a survey of the literature]. Sovereign yield spreads are the dominant metric to gauge the integration of debt markets, but measuring equity market integration is more challenging. Most of the existing research has used equity returns to measure the relative importance of an EU return factor (e.g. Hardouvelis, Malliaropulos and Priestley, 2006), dispersion or correlations trends (e.g. Adjaouté and Danthine, 2004), or the degree of news and volatility spill-overs among EU countries (see, for example, Baele, 2005; Fratzscher, 2002). A few studies have also investigated quantity-based measures; for example, Jappelli and Pagano (2008) document the degree of home bias over time.

We offer a different approach. We use stock market valuations of industry portfolios in different countries to assess the degree of bilateral integration in Europe and the impact of the EU between 1990 and 2007. Stock market valuations reflect financial integration through their impact on discount rates as well as economic integration through their impact on capitalized growth opportunities. As we argue below, integration should lead to "valuation convergence" of similar firms across different countries.

In contrast to existing studies on equity market integration, our method is essentially model-free, only requiring valuation ratios and therefore avoiding the joint hypothesis problem plaguing extant studies using equity return data. Valuation ratios also are much less volatile than equity returns allowing more powerful statistical tests. Concretely, we propose absolute differences of earnings yields, the inverse of price-earnings ratios, across industries in different countries, as an easily interpretable segmentation measure.

Our focus on valuation has the advantage that it captures the wider impact the EU may have had on integration before the recent financial crisis. For example, increased price 
competition may have also led to valuation convergence and be driven by EU membership $\bigsqcup^{1}$ It is, of course, of interest to disentangle discount rate (financial market integration) from cash flow (economic integration) effects.

We establish that between 1990 and 2007 EU membership reduced average bilateral earnings yield differentials by about 150 basis points in our most general specification. This is a large change in valuation differences. Using an empirical approach to separately measure expected returns and expected earnings growth rates, we find EU membership led to strong convergence of both, but the effect on discount rates was the largest. We also compare valuation differences in Europe with valuation differences computed from randomized U.S. portfolios, matched by industry composition and the number of firms per industry-country pair to our European data. At the end of 2007, bilateral valuation differentials within Europe were still significantly above the levels observed in U.S. data, but conditioning on EU membership, they had become indistinguishable from those observed in U.S. data in 2000.

Of course, EU membership is not exogenous; country characteristics that increase the likelihood of early EU membership, such as economic and institutional development, may well be correlated with a higher propensity to integrate with other member countries. Moreover, this convergence happened against the backdrop of a global integration process that led to valuation convergence across the world (see Bekaert, Harvey, Lundblad and Siegel, 2011). However, the strong EU effect we mentioned is conditional on a variety of cross-sectional and temporal controls, including a control for global integration. While it is very difficult to establish causality, the EU effect holds in a difference-in-differences specification that controls for country-pair and year fixed effects. It also survives and becomes even stronger in an instrumental variables regression, where we use the distance to Brussels as an instrument for EU membership. Many of the institutions of the EU are established in Brussels and a

\footnotetext{
${ }^{1}$ There is a large economics literature attempting to assess the degree to which the European Union did or did not succeed in integrating markets across member countries in a wide sense. While Krueger (2000) finds that labor mobility among member countries did not significantly increase after the elimination of the remaining restrictions in 1993, Nicoletti, Haffner, Nickell, Scarpetta and Zoega (2001) document that goods prices, especially for tradables, are more similar within the EU than among other OECD countries. Blanchard and Giavazzi (2002) argue that increased trade and cross-border investment among EU member countries have weakened the association between national savings and investments more among $\mathrm{EU}$ and in particular Euro member countries than among other OECD countries.
} 
larger distance from Brussels slows down EU ascension.

While much of the pre-crisis literature has stressed the effects of the introduction of the Euro on integration in Europe, by the end of 2007 we find the Euro did not significantly contribute to integration. Moreover, the EU effect is unchanged when the Euro introduction is added as an extra control.

Most of our paper focuses on the 1990-2007 sample period which covers the expansion of the EU across many countries as well as the completion of the "single market" that allows for the free movement of goods, capital, people, and services between EU members and the implementation of a large number of EU directives to harmonize regulation of capital markets and financial services.

We also confront the recent Eurozone crisis. We consider a monthly sample that extends the data through July 2012. Given that the crisis is such a massive event, it is reasonable to divide the empirical work into pre-crisis and full sample. Our main finding that EU membership increases integration, while Euro adoption does not, is robust using a full sample that includes the crisis.

The remainder of the paper is organized as follows. In Section 2, we present our segmentation measure and characterize its evolution over time. Because the segmentation measure may be affected by temporary fluctuations in valuations and is bounded from below by zero, we establish a benchmark using randomized U.S. portfolios. Section 3 sets out our main regression framework and establishes the main results. In Section 4, we consider potential channels through which EU membership may have affected valuation differentials, examining among others, trade, FDI, regulation, financial development and differences in real interest rates. In Section 5, we provide results based on data that include the recent Eurozone crisis. The final section offers some concluding remarks. 


\section{Integration through a valuation lens}

\subsection{A market segmentation measure}

As a starting point, consider the Gordon growth model, which assumes that the discount rate, $r$, is constant and expected earnings grow at a constant rate, $g$. If a firm pays out all earnings every year, its earnings yield simply is $r-g$. Hence, in this simple model, discount rates and growth opportunities are linearly related to the earnings yields. Assume that the world real interest rate is constant and systematic risk is industry rather than firm specific, as is typically assumed in capital budgeting. ${ }^{2}$ These assumptions are more plausible when the industry structure is quite granular so that industries are comparable across countries. Financial market integration then equalizes industry betas as well as industry risk premia across countries. Furthermore, assume that in economically integrated countries persistent growth opportunities are mostly industry rather than country specific or at least rapidly transmitted across countries ${ }^{3}$ It then follows that the process of market integration should cause valuation differentials between industries in different countries to converge. We build on this intuition to create bilateral valuation differentials that serve as our segmentation measure.

Specifically, let $E Y_{i, k, t}$ denote industry $k$ 's earnings yield in country $i$ at time $t$ and $E Y_{j, k, t}$ the corresponding value for the same industry $k$ in country $j$. Our main variable of analysis is the absolute value of the difference between the two industry valuations, $\left|E Y_{i, k, t}-E Y_{j, k, t}\right|$. The weighted sum of these bilateral industry valuation differentials is our measure of the degree of effective or de facto equity market segmentation between these two countries:

$$
S E G_{i, j, t}=\sum_{k=1}^{N_{i, j, t}} I W_{i, j, k, t}\left|E Y_{i, k, t}-E Y_{j, k, t}\right|
$$

where $I W_{i, j, k, t}$ is the relative market capitalization of industry $k$ and $N_{i, j, t}$ is the number of industries for country-pair $i, j$ at time $t$. The relative market capitalization of a given

\footnotetext{
${ }^{2}$ It is well known that that real interest rate variation does not account for much variation in valuation ratios.

${ }^{3}$ This is plausible as firms in the same industries face similar production processes and market conditions (again under the null of free competition and lack of trade barriers).
} 
industry is calculated as the combined market capitalization of the industry in both countries divided by the combined market capitalization of all industries in both countries. With this weighting scheme the industry structure of the country with the larger equity market has more influence on the segmentation measure.

Bekaert et al. (2011), contrasting local and global valuation ratios, point out a number of biases in this type of segmentation measure. Country-specific differences in financial leverage may cause different valuation ratios even when asset market betas are equalized. In a dynamic setting, financial and economic integration does not restrict the volatility of the shocks to earnings growth rates and discount rates, but they will nonetheless be reflected in valuation ratios. In addition, the number of firms in a particular industry should affect the accuracy of the measure. Given that we use absolute values of yield differentials, noise will bias the measure upward, so it should be decreasing in the number of firms present in the industry. However, it is straightforward to control for these biases in a regression analysis, which is what we do in this article.

Note that our measure requires nothing more than industry-level valuation ratios which are observed at every point in time. This contrasts with the standard approach in the international finance literature that employs estimated measures of segmentation based on, for

example, the evolution of equity return correlations or systematic risk exposures (e.g., world market portfolio betas); see Bekaert, Hodrick and Zhang (2009) and the references therein. However, the construction of such measures requires both historical data and a particular estimation method. Furthermore, the interpretation of these measures often requires a formal international asset pricing model, about which there is little consensus.

\subsection{An initial assessment of integration in Europe}

We construct our measure of bilateral valuation differentials, $S E G$, for a sample of 33 European countries listed in Table 1, using monthly firm-level data from Datastream from 1990 to 2007. While we construct monthly SEG measures, our subsequent analysis is at the annual frequency given the availability of other variables. We identify all local equity securities in these countries covered by Datastream and traded on a public exchange. Depository 
receipts as well as preferred stocks are excluded, as are securities whose International Securities Identification Number (ISIN) is not local. We then obtain monthly earnings yield, market capitalization (in USD) as well as USD return data. Datastream generally reports trailing 12-month earnings yields, where negative yields are set to zero. In addition, we delete earnings yields that are larger than one. Using Datastream's industry classification system $\mathbb{4}^{4}$ we form 38 value-weighted industry portfolios for all countries. For each country-pair, we compute $S E G_{i, j, t}$ as described in (1). The number of country-pairs with non-missing data is growing over time, from 120 country-pairs in 1990 to a maximum of 528 country-pairs. To avoid the possibility of mis-measured outliers influencing the full sample, we delete, for every year separately, observations with a segmentation measure equal to or larger than the 99th percentile of the segmentation measure for that year. The complete data set contains 5,665 observations.

Appendix Table 1 (Panel A) reports summary statistics, suggesting that on average segmentation between EU member countries was about two percentage points lower than for the rest of the sample. This could reflect the EU's efforts with respect to general economic integration (e.g. trade), which have been ongoing for decades, or, efforts with respect to capital account liberalization (completed in 1992) and the harmonization of capital market regulation (still ongoing). Because the financial market integration process was jump-started by the Single European Act of 1986 with countries such as France, Italy and Belgium, relaxing capital controls a few years later, we start the sample only in 1990. However, our subsequent results are robust to starting the sample in 1980.

During our sample period, the segmentation level among EU countries was $3.8 \%$. Given the segmentation measure uses absolute differences in earnings yields and need not be zero under the full null of financial and economic integration, it is not clear whether this level is "close" to integration or not. Therefore, we use U.S. equity market data to measure the average level of segmentation for fictitious country-pairs that mimic our European pairs, but exclusively reflect U.S. valuations. To the extent that the U.S. is financially and economically

\footnotetext{
${ }^{4}$ Datastream employs the Industry Classification Benchmark (ICB) framework. For a list of the 38 industries used in our study, see the Online Appendix. The industry is determined by the source of a firm's revenue or the source of the majority of its revenue. Firms that are not classified as one of these 38 industries are excluded from our study.
} 
integrated, this exercise provides us with a meaningful benchmark to judge whether European country-pairs are segmented or not. In particular, we identify all U.S. stocks that are covered by CRSP and Compustat. We obtain four quarter trailing earnings from Compustat and combine these with firm-level equity market capitalization from CRSP to calculate firm-level earnings yields.5 As in our European data set, we set negative earning yields to zero and earnings yields larger than unity to missing. Next, we use these U.S. data to form countryindustry portfolios by randomly drawing firms from the U.S. data set, mimicking the number of firms found in a given country-industry portfolio in a given year in our European data. We draw from the U.S. sample with replacement, as the total number of European firms per industry can be larger than the total number of available U.S. firms in that industry ${ }^{6}$ We then use these U.S. data based country-industry portfolios to calculate bilateral segmentation measures as described above. We repeat this process 500 times and thus obtain a distribution of the average level of bilateral segmentation to which we can compare the actual level of segmentation observed in Europe as well as in the European Union.

Figure 1 shows the average random U.S. benchmark segmentation level corresponding to the set of all European country-pairs from 1990 until 2007, together with a 90\% confidence interval. Note that, even though the U.S. is an integrated market, the level of measured segmentation was mostly in the 2 to $4 \%$ range. Also shown is the average segmentation level for all EU and for all non-EU European country-pairs.7 With the exception of 2005, the valuation differentials of non-EU country-pairs were above the $90 \%$ confidence interval of valuation differences in the U.S. In contrast, the measured segmentation levels across EU countries were similar to those in the U.S. by 2000. After 2000, segmentation was again larger across EU members than in the U.S. but still lower than for non-EU pairs. Importantly, this does not necessarily mean that EU membership was the cause of integration. For

\footnotetext{
${ }^{5}$ In particular, we obtain "Income Before Extraordinary Items" (IBADJQ) for the previous four quarters. We pair these earnings with the market value of all outstanding equity securities at the end of December. We only use earnings data up to the end of September. Using industry information provided by Compustat (GICS and SIC codes), we assign an ICB code to each firm. For about 3\% of all observations, we are unable to identify the appropriate ICB code.

${ }^{6}$ In a robustness exercise, we repeat the experiment, but ensure that each country-industry portfolio contains at least one unique firm. In very few cases, this is impossible as the total number of U.S. firms in a given industry is smaller than the number of countries. We find that our results are essentially unchanged.

${ }^{7} \mathrm{EU}$ country-pairs are pairs where both countries are EU members, all other country-pairs are non-EU country-pairs.
} 
example, a plausible alternative hypothesis is that the general movement towards global market integration led to narrower valuation differentials across equity markets in the EU. Nevertheless, this still begs the question of why this convergence was more pronounced for EU country-pairs than for Europe as a whole. In the next section, we use a regression framework to address this question.

One potential problem with a focus on our full sample is that the sample is unbalanced. Moreover, with the emergence of Eastern European countries in the 1990s, the sample composition changes substantially over time. We therefore focus our initial analysis on a balanced sample of 120 country-pairs for which we have data since 1990 8 This sample excludes all Eastern-European countries; see Table 1 for a list of all countries included. For this balanced sample of 2,160 observations, Panel B of Appendix Table 1 shows EU membership was associated with lower segmentation (about 1.25\%).

\section{The EU and integration}

\subsection{Benchmark empirical model}

In this section, we investigate the effect of EU membership on bilateral equity valuation differentials, controlling for several potentially confounding factors. The linear regression model is:

$$
S E G_{i, j, t}=a+b_{E U} E U_{i, j, t}+b_{X} X_{i, j, t}+c_{i, j}+d_{t}+\epsilon_{i, j, t}
$$

where $E U_{i, j, t}$ is an indicator that is one in year $t$ if both countries are EU members and zero otherwise, $X_{i, j, t}$ represents a set of controls, and $c_{i, j}$ and $d_{t}$ represent country-pair and year fixed effects. All standard errors are robust to arbitrary correlation over time within country-pairs and across country-pairs within years (see Thompson, 2009; Cameron, Gelbach and Miller, 2006; Bertrand, Duflo and Mullainathan, 2004).9 Appendix Table 2 discusses

\footnotetext{
${ }^{8}$ Differently from the full sample, we do not drop observations in the top one percent of the segmentation distribution.

${ }^{9}$ Adjusting standard errors for contemporaneous correlation across country-pairs is particularly important given that we use a measure of bilateral segmentation. Country-pairs that share one country are not independent of one another. We account for cross-sectional correlation by calculating the variance of the coefficient estimates as $\left(W^{\prime} W\right)^{-1}\left(\sum_{t} W_{t}^{\prime} \epsilon_{t} \epsilon_{t}^{\prime} W_{t}\right)\left(W^{\prime} W\right)^{-1}$ where $W_{t}$ is the $N_{t} \times k$ matrix of all $k$ right hand
} 
the data sources and construction of all variables used in our analysis.

Table 2 reports the result for the balanced sample of a regression of country-pair valuation differentials on the EU indicator and different sets of controls. The first specification includes the EU indicator and the sum of the number of firms from both countries (in natural logs) used to calculate the segmentation measure 10 as well as the average absolute difference in industry leverage, in industry earnings growth volatility, and in industry return volatility for a given country-pair in a given year. These variables may cause variation in the $S E G$ measure unrelated to the degree of integration. The first specification suggests that absolute valuation differentials were about one percentage point lower between EU member countries. As expected, segmentation was negatively and significantly associated with the number of firms, and positively associated with leverage and volatility differences.

The second specification in Table 2 also includes three country-pair characteristics. Given it is natural to expect that countries with similar economic development have similar growth opportunities and narrower valuation differentials, we include the average difference in per capita GDP in 1990. Since EU membership is likely correlated with economic development, this is a potentially important control variable. One of the main findings in the home bias literature is that investors tend to invest relatively more in countries that are close by and "familiar" (see Chan, Covrig and Ng, 2005; Portes and Rey, 2005). To control for such familiarity effects, we include the distance between the two countries in a countrypair (measured in 1,000 kilometers between the most important cities) as well as a common language indicator as additional controls. Note that the inclusion of these time-invariant controls actually increases the absolute EU effect to 160 basis points. Economic development differences surprisingly decrease segmentation. The distance between two countries had a

side variables for all $N_{t}$ country-pairs in year $t$. Consider a regression of the segmentation measure on the EU indicator alone (point estimate -0.0169), but including country-pair and year fixed effects. The heteroskedasticity robust standard error for the EU effect is 0.0023 , while accounting for contemporaneous cross-sectional correlation yields a standard error of 0.0041. Finally, accounting for contemporaneous cross-sectional correlation as well as time-series correlation within country-pairs (as we do in all specifications) yields a standard error of 0.0049 .

${ }^{10}$ In unreported results, we consider additional controls related to the number of firms used to calculate the average bilateral industry valuation differential. In particular, we include the minimum as well as the absolute difference of the number of firms averaged across the relevant industries. The latter may also capture competitive differences across countries. We find that the estimated effect of joint EU membership is unchanged. 
positive and statistically significant effect, suggesting that an additional 1,000 kilometers in distance was associated with an additional 0.65 percentage point valuation differential. A common language appears to have had little effect on valuation differentials.

The third specification in Table 2 adds two time series variables. Most importantly, we distinguish regional from global integration by including the earnings yield differential between the "Core European" countries"11 and the U.S. This differential should capture integration between the U.S. and Europe ('global integration') and could therefore indirectly affect valuation differentials across European countries. We also include the market earnings yield for Core Europe because the variability of earnings yields may be higher at higher yield levels. Both variables are statistically significant and have the expected sign. The effect of segmentation between Europe and the U.S., reflecting the underlying trend of global market integration, was economically important, as for every $1 \%$ decrease in global segmentation, intra-European differentials decreased by $1.5 \%$. The time controls reduce the EU effect back to $1 \%$, but it remains highly significant. Note that the addition of controls has also increased the $R^{2}$ from $12 \%$ in specification 1 to $33 \%$ in specification 3 .

While we have attempted to control for factors that might affect bilateral valuation differentials as well as EU membership, it remains possible that additional unobservable characteristics led to a bias in our coefficient estimates for the EU indicator. To the extent that these unobservable characteristics are time-invariant, we can address the endogeneity concern by including country-pair fixed effects (see Glick and Rose (2002) for a similar application), essentially identifying the change in segmentation due to a change in membership status. In specification 4, we reestimate specification 1 augmented by country-pair and year fixed effects, which yields a difference-in-differences (DID) estimation. In this specification, we, of course, cannot include time-invariant or country-invariant controls. Not surprisingly, the $R^{2}$ increases dramatically (to $47 \%$ ), but at -143 basis points (bp) the EU effect becomes more, not less important. Examining the four different specifications, controlling for crosssectional characteristics seems to increase the magnitude of the effect whereas adding time controls reduces it. The DID specification yields a stronger EU effect on segmentation than a

\footnotetext{
${ }^{11}$ Namely Belgium, Denmark, France, Germany, Ireland, Italy, Luxembourg, the Netherlands, and the United Kingdom.
} 
simpler specification, such as specification 1, which fails to properly control for time-invariant country-pair effects and global integration.

Finally, note that the EU effect extends over the two decades of our 1990 to 2007 sample period. Using the DID specification, we find, in untabulated results, significantly negative point estimates of $-1.52 \%$ for the 1990 s and of $-1.11 \%$ for the 2000 to 2007 period.

\subsection{Discount rates or growth opportunities?}

From the Gordon growth model, we know that the earnings yield reflects the cost of equity capital and/or expected earnings growth. While we measure absolute differences, EU membership typically reduced earnings yields towards the levels observed for existing EU members. Hence, our results indicate that EU membership was accompanied by a reduction in the cost of capital and/or an improvement in growth opportunities. Measuring these effects separately is of considerable interest, because the EU's impact on financial market integration likely operated through changes in the cost of capital, whereas changes in expected earnings may have been associated with a variety of EU-induced measures to promote trade, labor mobility, and competition.

Measuring expected returns and expected earnings growth rates is challenging. To do so, we specify an empirical model of annual returns and earnings growth rates as well as earnings yields at the country-industry portfolio level, specified at a monthly frequency. Specifically, we estimate a system of three equations:

$$
\begin{aligned}
r_{i, k, t+12}= & \alpha_{0, t}+\alpha_{1, t} Z_{i, t}^{D R}+\alpha_{2, t} Z_{t}^{D R}+\epsilon_{i, k, t+12}^{r} \\
g_{i, k, t+12}= & \delta_{0, t}+\delta_{1, t} Z_{i, t}^{G O}+\delta_{2, t} Z_{t}^{G O}+\epsilon_{i, k, t+12}^{g} \\
E Y_{i, k, t+12}= & \gamma_{0}+\gamma_{D R}\left(\alpha_{0, t+12}+\alpha_{1, t+12} Z_{i, t+1}^{D R}+\alpha_{2, t+12} Z_{t+1}^{D R}\right)+ \\
& \gamma_{G O}\left(\delta_{0, t+12}+\delta_{1, t+12} Z_{i, t+12}^{G O}+\delta_{2, t+12} Z_{t+12}^{G O}\right)+\epsilon_{i, k, t+12}^{E Y}
\end{aligned}
$$

where $r_{i, k, t+12}$ and $g_{i, k, t+12}$ are the realized annual equity returns and earnings growth rates (in USD), respectively, for the country $(i)$ - industry $(k)$ portfolio between time $t$ and $t+12$; $Z_{i, t}$ and $Z_{t}$ are vectors of local and international predictors of returns and earnings growth 
rates. The parameters $\alpha_{m, t}$ and $\delta_{m, t}$, for $m=0,1$, and 2 , reflect interactions with the country specific EU indicator, $E U_{i, t}$, as underlying our analysis is the possibility that the EU causes a structural break in the pricing relationships:

$$
\begin{gathered}
\alpha_{m, t}=\alpha_{m, 0}+\alpha_{m, 1} E U_{i, t} \\
\delta_{m, t}=\delta_{m, 0}+\delta_{m, 1} E U_{i, t}
\end{gathered}
$$

Specified in this way, discount rates and growth opportunities depend on local as well as international industry and country factors (interacted with a EU indicator variable) and earnings yields are a linear function of the predicted discount rates and growth opportunities. The specific predictors that are included in each equation are selected based on untabulated linear regressions of returns and earnings growth onto a set of predictors consisting of lagged local industry earnings growth, industry dividend yields at the local Core-European and world level, the U.S. Treasury yield, the U.S. default spread, the U.S. terms spread, as well short term local government yields and local as well as U.S. industrial production growth. A given predictor is included in the final model specification in (3), when the absolute value of its $t$-statistic is at least one. The final specification is given in the online Appendix.

We estimate (3) using a 2-step GMM estimator ${ }^{12}$ The rationale for the three equation system is straightforward. Pure linear regressions may yield risk premia and expected earnings growth rates that are too variable and noisy. Given that the earnings yield is not very variable, this over-identification in the GMM system should lead to more precise estimates of discount rates and growth opportunities. We stop short of assigning all variation in earnings yields to either discount rates or expected earnings growth rates, as is common in the asset pricing literature, as there is no well accepted way to split up the unexplained variation to either discount rates or expected earnings growth rates. Our online Appendix reports the coefficient estimates for the country-industry portfolios from our balanced sample. The estimate for $\gamma_{D R}$ is positive and $\gamma_{G O}$ is negative, i.e. earnings yield are higher when expected

\footnotetext{
${ }^{12}$ Specifically, in the first step the weighting matrix assumes that the three equations above are independent (that is, elements corresponding to covariances between any two equations are set to zero), the rest of the weighting matrix is of the form $\left(Z^{\prime} Z\right)^{-1}$, where $Z$ represent all right hand side variables of a given equation. We use an optimal heteroskedasticity- and autocorrelation- (20 lags) robust weighting matrix in the second step.
} 
returns (discount rates) are higher and when expected earnings growth rates (growth opportunities) are lower. The estimated linear combination of predicted returns and earnings growth rates explains about $17 \%$ of the variation in industry earnings yields.

Let $D R_{i, k, t}$ be the estimated country-industry discount rate (the fitted value of the return equation) and $G O_{i, k, t}$ the estimated country-industry growth opportunity (the fitted value of the earnings growth rate equation). We can then form two additional measures of segmentation between countries $i$ and $j$ :

$$
\begin{aligned}
S E G_{i, j, t}^{D R} & =\sum_{k=1}^{N_{i, j, t}} I W_{i, j, k, t}\left|D R_{i, k, t}-D R_{j, k, t}\right| \\
S E G_{i, j, t}^{G O} & =\sum_{k=1}^{N_{i, j, t}} I W_{i, j, k, t}\left|G O_{i, k, t}-G O_{j, k, t}\right|,
\end{aligned}
$$

where, as above, $I W_{i, j, k, t}$ is the relative market capitalization of industry $k$ and $N$ is the number of industries. The first measure, $S E G^{D R}$, captures the degree to which industrylevel discount rates differed between two countries, and hence, the degree to which markets were not financially integrated. However, the second measure, $S E G^{G O}$, highlights the degree to which industry-level expected growth rates differed for a country-pair, which could reflect economic integration. As above, we focus on segmentation measured in December of each year, starting, when available, in 1990, and ending in 2007, for a maximum of 120 countrypairs with a total of 1,962 observations ${ }^{13}$ The mean (untabulated) of bilateral discount rate segmentation $\left(S E G^{D R}\right)$ is 0.0336 and the mean of bilateral segmentation with respect to earnings growth rates $\left(S E G^{G O}\right)$ is 0.0102 .

For each measure, we separately estimate the same regressions (equation 2) as for the aggregate segmentation measure $(S E G)$. The results, reported in Table 3, suggest that joint EU membership was associated with significantly lower cross-country differences in discount rates, varying between 3.64 and 4.34\%. The financial integration effect was sizeable and consistent with the evidence in Hardouvelis, Malliaropulos and Priestley (2007) who show that the cross-country dispersion of industry-level cost of equity dropped in Europe in the

\footnotetext{
${ }^{13}$ Strictly speaking, the data set used here is unbalanced, as it is slightly smaller than our balanced data set (120 country-pairs with 2,160 observations between 1980 and 2007) due to the limited availability of some of the return and growth predictors.
} 
1990s. However, the integration effects associated with EU membership went beyond the discount rate channel and also implied cross-country differences in earnings growth rates decreasing between 1.35 and 4.00\%. For every specification, the EU effect was larger for $S E G^{D R}$ than for $S E G^{G O}$. We conclude that the EU effect on valuation differences was due to both financial and economic integration, with the effect of financial integration somewhat stronger.

\subsection{The EU or the Euro?}

Another momentous change in Europe was the introduction of the single currency, the Euro, in 1999. Most, but not all, EU countries adopted the Euro, with some joining later and others, such as the UK, Sweden, and Denmark, declining to join the currency union. Given that Euro adoption is often viewed as the culmination of the process towards economic and monetary integration within the EU, it is conceivable that our finding that the EU significantly contributed to equity market integration is in fact due to the adoption of the Euro, rather than to EU membership per se.

In fact, there has been more research on the effects of Euro adoption than on the effects of EU membership. This research has included the trade impact of the Euro (see, e.g., Micco, Stein and Ordoñez, 2003; Santos Silva and Tenreyro, 2010) and the effects of the Euro on product and labor markets (see, e.g., Alesina, Ardagna and Galasso, 2008). Of more interest to us is research focusing on the financial effects of the Euro. Bris, Koskinen and Nilsson (2008) show that corporate valuations increased in the Euro member countries that previously had weak currencies, possibly due to lower interest rates and costs of equity. Hardouvelis et al. $(2006,2007)$ claim that Euro adoption, rather than global trends or EU membership, served to integrate European equity markets in the 1990s. Cappiello, Kadareja and Manganelli (2010) find that equity return comovements between EU member states increased after 1998, especially for country pairs that have adopted the Euro. Finally, Bartram and Wang (2011) find more stock market dependence among countries that adopted the Euro.

While it is possible that our results are related to the introduction of the Euro, it is also 
conceivable that EU membership and the move towards global market integration already integrated EU equity markets before the advent of the Euro. By 1999, regional and global market integration may have moved far enough along for the Euro to have only small effects. In addition, ex ante we would expect the process of financial market integration to be more important for equity valuations than the adoption of a single currency. This is because currency movements account for only a small part of the total variation in equity returns and the variability of intra-Europe exchange rate changes before 1999 was quite limited.

In Table 4, Panel A, we add a Euro indicator variable to the various specifications from Table 2. The Euro indicator takes on the value of one if both countries in a country-pair were part of the Euro area in a given year and is zero otherwise. In specification 1, where we only include the EU, the Euro indicator, and the "bias control variables" (see Section 2.1), we find that the adoption of the Euro had a small and statistically insignificant negative effect on valuation differentials. This conclusion holds when we introduce additional control variables (specifications 2 and 3). In specification 4, country-pair and year fixed effects are included and the Euro effect even turns positive. These results suggest it is hard to make a case for a strong Euro effect on market integration within Europe during our sample period. Importantly, comparing Table 2 to Table 4 , the EU effect is not significantly impacted by the introduction of the Euro indicator.

It is quite conceivable that some of the effects ascribed to the introduction of the Euro in the literature are simply induced by EU membership. For example, Hardouvelis et al. (2006) find that several Euro adopting countries experienced increased equity market integration during the 1990s, while the UK did not, but they do not formally compare the effects of EU membership and Euro adoption. Moreover, research studying other aspects of integration have also found that the EU generated larger effects than the Euro. For example, Engel and Rogers (2004) find no tendency for goods prices to converge after January 1999, but find a significant reduction in price dispersion throughout the decade of the 1990s. Goldberg and Verboven (2005) similarly document substantial price convergence in the EU's car market throughout the nineties, although absolute price differentials persisted until the end of their sample in 2000. Hence, the EU, not the Euro, led to the integration of consumer markets.

Note that there may have been strong indirect effects of the Euro that were related to 
the original mission of the EU. After all, the Maastricht Treaty, drafted in 1991 and officially adopted in November 1993, set out a path to harmonize national regulation which would culminate in economic and monetary union and the eventual adoption of the Euro. It is possible that some of the EU effects we detect were related to changes only occurring in the nineties with the adoption of the Maastricht Treaty. However, in our opinion, the Euro effect should measure the actual effect of the single currency, not the capital, trade, and labor market integration that may have preceded it.

Nevertheless, we do test an additional specification that changes the timing of the Euro effect. We recognize that preparations for the Euro may have been long underway and countries may have undertaken measures to limit exchange rate volatility some time before the Euro was actually adopted (for example, by creating a target zone relative to the Euro). In addition, Frankel (2005) argues that a currency union may already generate effects on trade patterns before it actually goes into effect, as soon as the negotiations convince the corporate sector it will actually happen. Fratzscher (2002) claims that European markets only became highly integrated after 1996, and that the move to integration was in large part impacted by the drive towards the Euro, and in particular the elimination of exchange rate volatility and uncertainty in the process of monetary unification.

We test the anticipation effect directly by replacing the Euro indicator by a measure inversely related to exchange rate volatility. To do so, we collect bilateral daily exchange rates for all of our countries relative to the Deutsche Mark before 1999 and relative to the Euro thereafter. We use these data to compute a measure of realized exchange rate volatility, $\sigma$ (the square root of the sum of squared daily exchange rate changes during a year). We transform the volatility into a stability measure on a $[0,1]$ scale by computing $1 / \exp (100 \sigma)$. Thus, a country with zero exchange rate volatility takes on a value of one (this will be true for all Euro countries once they adopt the Euro); a country with $12 \%$ annual volatility (roughly that of a major floating currency) would effectively receive a stability measure of zero. For a country-pair, we employ the average value of the two countries in a pair. In Panel B of Table 4, we show that the effect associated with this alternative measure based on exchange rate volatility delivers very similar qualitative findings to the binary Euro indicator. While the stability variable does indeed move up prior to the introduction of the Euro as exchange 
rate volatility decreases, the estimated Euro effect is only marginally stronger. Further, the introduction of this alternative indicator has little impact on the coefficient on the EU indicator.

\subsection{Robustness}

So far, we have documented a significantly lower earnings yield differential associated with EU membership, with the EU effect being about -140 basis points in a DID specification. The EU effect on segmentation dominated the effect of Euro adoption. In Table 5, we report three robustness checks.

First, we consider a segmentation measure that is constructed as in (1), but where we only include those industries that contain at least five firms in a country and year. This should improve the precision of our segmentation measure. Implementing this rule for our balanced sample, we lose 15 observations, yielding a sample of 2,145 observations ${ }^{14}$ The EU effect is now larger by almost 100 basis points, suggesting that measurement error may have reduced our estimate. In the specification with the Euro indicator, the EU effect remains unaltered and the coefficient on Euro adoption is not significantly different from zero.

Second, so far, we have defined our segmentation measure as the value-weighted average industry valuation differential. An industry's value is the sum of the industry's equity market capitalization across both countries in a country pair. In the second robustness exercise, we report the EU effect when measuring bilateral segmentation as the equally weighted average across industries $[15$ For consistency, we also replace the control variables related to leverage, earnings growth volatility, and return volatility with their equally weighted counterparts. The estimate of the EU effect is again quite similar to the one for the valueweighted segmentation measure, at -125 basis points. Adding the Euro again does not change the EU coefficient and the Euro effect is once again insignificant.

In the third robustness exercise, we use the natural logarithm of the segmentation measure

\footnotetext{
${ }^{14}$ For 15 country-pair years, no common industries are left to construct our segmentation measure. In all other cases, the segmentation measure exists, but will differ from the measure used so far, whenever a previously included industry consists of less than five firms. Strictly speaking the resulting sample is no longer balanced.

${ }^{15}$ We again only include those industries that contain at least five firms in a country and year. Without this requirement, the corresponding EU effect drops to $-21 \mathrm{bp}$.
} 
to address its asymmetric distribution as well as potential outliers. Evaluated at the average segmentation level of 0.0380 , the predicted absolute EU effect on $S E G$ is about -70 basis points. The Euro effect is again insignificant.

\subsection{Alternative estimates of the EU effect}

In this section, we consider two alternative estimates for the EU effect. First, we investigate whether the EU effect was also present in the full, but unbalanced sample that uses all of our data. Second, we investigate an alternative identification strategy using instrumental variables estimation.

\subsubsection{Full sample}

We can double our sample size if we drop the requirement of a balanced sample, and include data on mostly Eastern European countries that become available throughout the 1990s. In Table 6, Panel A, we repeat the specifications of Table 2 for the full sample. Given that Eastern European countries were transitioning from the Soviet era to market-based economies over the course of our sample, we include an Eastern Europe indicator that is one if at least one country in a country-pair is in Eastern Europe and zero otherwise. Since Eastern European countries were on average less integrated, this indicator variable is highly significant at $1.28 \%$. Of course, in the DID specification, country effects control for any Eastern Europe "specialness." We find that the EU effect is highly significant in all four specifications, ranging from -1.68 in specification 1 to -0.84 in the DID specification. The three robustness exercises in Panel B (the use of at least five firms per country-industry, equally weighted or logged segmentation measures) also yield a significantly negative EU effect of similar magnitude in every case ${ }^{16}$ We have conducted a series of additional robustness exercises. For example, we have dropped countries such as Turkey and Russia from the sample, but the EU effect remains statistically significant and of the same order of magnitude.

Finally, while we do not report these results, adding the Euro indicator again does not alter the EU effect, and the Euro effect is never statistically significantly negative. Moreover,

\footnotetext{
${ }^{16}$ Note that in the case of the logged segmentation measure we have included all observations, including the top one percentile of observations, which in the case of the full panel are excluded in our main specification.
} 
the discount rate effect continues to dominate the expected earnings growth rate effect. These results are available upon request.

\subsubsection{Instrumental variables regression}

So far, we have used country-pair fixed effects to address endogeneity concerns. In this subsection, we propose and implement an instrumental variables (IV) approach that uses a new and potentially useful instrument for EU membership, namely the distance to Brussels. Much of the momentum to start, enlarge, and expand the scope of the European Union originated in the Benelux countries and France. The governing institutions of the European Union (EU) are not concentrated in a single capital city; they are instead mostly based across three cities (Brussels, Luxembourg, and Strasbourg). However, Brussels has become the primary EU location, hosting a seat of each major institution and now the European Council. It is possible that EU membership of a given country is negatively correlated with the distance of a country to Brussels, a clearly exogenous variable.

The procedure for EU accession is lengthy, requiring local connections and information gathering, and the negotiation process involves countless meetings, taking place, mostly, in Brussels (see e.g. Nicolaides and Boean, 1996). It is conceivable that shorter distances lead to a faster accession process. Fischer, Sahay and Gramont (1998), studying the economic distance between the Eastern European entrants and Brussels, also mention that physical distance should matter, but do not elaborate on why. The sociology literature on "localism" offers a different perspective on why the distance to Brussels may promote EU accession. Berezin and Diez-Medrano (2008) argue that the decision to join the European Union also depends on popular support for EU membership in the candidate countries. They then show, using Eurobarometer data, that such local support depends negatively on the distance to Brussels, a result they interpret as driven by identification with Europe, trust towards European institutions, and confidence in the ability to influence European institutions all depending on physical distance. No instrument is perfect, of course, and while the distance to Brussels is clearly exogenous, it may still correlate with the error term in the $S E G$ regression through indirect channels. For example, it may be correlated with the distance between two countries, which we demonstrated affects $S E G$. Therefore, the distance between 
two countries will always be included as a control variable in all IV specifications.

Since we are interested in predicting the EU membership of a country-pair and since the distance to Brussels likely differs between the two countries in a country-pair, we propose the maximum distance to Brussels for a given pair as an instrument for the EU indicator. With 2,905 kilometers, Cyprus has the largest distance to Brussels in our data set (see Appendix Table 1 for summary statistics).

Table 7, Panel A, left column, provides evidence on the usefulness of the proposed instrument. We report the results from a linear probability model of the following form:

$$
E U_{i, j, t}=a+b_{D B} D B_{i, j}+b_{X} X_{i, j, t}+d_{t}+v_{i, j, t}
$$

where $E U_{i, j, t}$ represents the $\mathrm{EU}$ membership indicator, $D B_{i, j}$ the maximum distance to Brussels for country-pair $i, j ; X_{i, j, t}$ represents control variables from the segmentation model and $d_{t}$ year fixed effects. The control variables are the same ones as the ones we used before, of course excluding pure time series variables.

As expected, during our sample period a longer maximum distance to Brussels was associated with a lower membership probability for a country-pair, with the coefficient highly significantly different from zero. As to the other variables, absolute differences in economic development and in financial characteristics, such as leverage and earnings growth and return volatility, lowered the probability of joint EU membership. Membership was also less likely for country-pairs with at least one Eastern European country and, maybe surprisingly, with a common language. On the other hand, country pairs with more developed equity markets, as proxied for by the number of publicly traded firms, as well as, again surprisingly, country pairs that are further apart were more likely to be EU members. However, the latter effect is not statistically significant.

In addition to the coefficient estimates, we report the adjusted $R^{2}$, the partial $R^{2}$ that reflects the contribution of the proposed instrument as well as the $F$-test statistic for the test $b_{D B}=0$. As before, standard errors are robust to arbitrary correlation over time within country-pairs and across country-pairs within one year. While no critical values exist for the $F$-test statistic in the presence of non-i.i.d. errors, Staiger and Stock (1997) suggest a value 
of 10 as a lower boundary to reject weak identification. The partial $R^{2}$ is around $4 \%$ and the $F$-test statistic is substantially larger than the approximate threshold value of 10 .

The second column in Panel A presents the effect of EU membership using the distance to Brussels as an instrument. We find that EU membership retains its negative effect on bilateral valuation differentials. Compared to our previous result in Table 6, the effect is more prominent, but the standard errors also increase, somewhat reducing the level of significance. This suggests that country-pairs with higher valuation differentials were more likely to become EU members, biasing the previous results against finding an EU effect ${ }^{17}$

We also explore a bivariate model which jointly estimates the probability of a countrypair being EU members, using a probit specification, and the effect of the EU membership on bilateral segmentation. Assuming that the error terms of both equations, the linear segmentation equation and the non-linear probit model for EU membership, follow a bivariate normal distribution, we estimate the model via maximum likelihood estimation. Panel B of Table 7 reports results for the bivariate model. For the membership equation (column "EU"), we report marginal effects instead of model parameters 18 The results for the membership model are qualitatively the same as those from the linear probability model reported in Panel A. The results for the segmentation model (column "SEG") again yield similar results. Segmentation between country-pairs that were EU members was significantly lower than for non-EU pairs. The EU effect of -253 basis points is slightly less pronounced than suggested by the corresponding IV regression. All other covariates have the expected sign.

\section{The channels of integration}

That during our sample period EU membership was associated with increased bilateral financial and economic integration, is, in principle, no surprise. Since its inception in 1957, the EU has promoted the free movement of goods, services, capital, and people. While the process is far from complete, the ultimate goal of the EU has been to achieve economic and

\footnotetext{
${ }^{17}$ Barro and Tenreyro (2007) similarly find that the effect of currency union membership onto trade increases once they use an IV approach.

${ }^{18}$ Marginal effects are calculated at the sample mean for continuous variables, but represent a discrete change for indicator variables.
} 
financial integration. Here we explore whether we can ascribe the observed increase in effective integration to specific channels, such as trade integration, or changes in financial market regulation. We assess whether these channels can explain the EU effect on valuation differences by adding these variables to our DID specification from Tables 2 (balanced sample) and 6 (full sample). Table 8 reports results for different sets of channels. We always show the EU effect in a regression without the channel variables to contrast how the various channels reduce the EU effect. We do so separately for the balanced as well as the full sample. Given that we have established that the direct EU effect on integration dominated the Euro effect, we focus on the EU effect. To be clear, our exercise is designed to eliminate the EU effect.

In specification 1, we start with proxies for bilateral trade, equity market development and openness as well as information flow, which are available for all observations in our balanced and full samples and which are part of all following specifications. Trade integration is a primary goal of the EU and hence a natural channel of integration. We collect data on country-pair annual trade volume (exports plus imports) from Datastream and scale it by the average GDP of the two countries in a country-pair. We note that the effect of increased trade on valuation is perhaps not entirely obvious. Increased trade opportunities may indeed have caused cash flow processes to be more correlated as business cycle transmission intensifies (Frankel and Rose, 1998), but it may also have led to more specialization. However, we control for the latter by only comparing earnings yields on an industry-by-industry basis. In addition, Aviat and Coeurdacier (2007) show that trade and financial integration are positively correlated.

Equity market openness should have led to similar discount rates across countries for firms with similar systematic risks, which we proxy by the industry to which a firm belongs. We measure de jure equity market openness based upon the the market capitalization of the S\&P investable relative to the S\&P global indices in each country, following Bekaert (1995) and Edison and Warnock (2003). The S\&P's global stock index aims at fully representing the local stock market whereas the investable index includes only stocks that are available to foreign investors and that meet minimum size and liquidity criteria. A ratio of one therefore means that all of the stocks in the local market are available to foreigners. For this measure, both the average level across the two counties in a country-pair (openness) 
and the absolute difference between two countries in a country-pair, indicating (the lack of) regulatory harmonization, are important. We include both.

Bekaert and Harvey (1995), Levine and Zervos (1998), and Guiso, Jappelli, Padula, Pagano, Martin and Gourinchas (2004) document that financial development actually fosters financial integration. We use the fraction of equity market capitalization over GDP (MCAP/GDP) as a measure of equity market development. Specifically, for each countrypair, we again include the average of the two fractions as well as the absolute difference between them.

Finally, the EU may have promoted the flow of information across EU countries. As a proxy, we use the number of telephones (fixed and mobile) per 100 inhabitants. Again, our base set of channel variables includes both the level and the absolute difference.

The results for specification 1 suggest that these channels lowered segmentation (in relative terms) by about $4 \%$ in the case of the balanced sample and by about $25 \%$ in the case of the full sample, rendering the EU effect insignificant in the latter case.

In the following four specifications, we explore additional channels which are not available for all observations 19 In specification 2, we use a financial reform index to capture EU harmonization of financial regulation. The index, available from the IMF, summarizes country-specific credit and security market regulation, interest rate controls, banking regulation and supervision, capital account restrictions, and privatization for a large set of countries between 1973 and 2005 We form bilateral averages as well as absolute differences in this financial reform index and include both variables as potential channels of integration. The results are similar to those in specification 1 . We also considered using an alternative index of financial regulatory harmonization based on country-specific implementation dates of the EU's 1998 Financial Services Action Plan (FSAP) (see Kalemli-Ozcan, Papaioannou and Peydró, 2012). But since the index is essentially undefined before 1999, we decided against

\footnotetext{
${ }^{19}$ Dropping missing observations from the balanced sample would make the balanced sample substantially unbalanced. We therefore impose for each specification that the balanced sample is indeed balanced, by only including country-pairs with non-missing observations in 1990.

${ }^{20}$ Each policy area is evaluated with respect to the amount of government control or interference and where appropriate the openness to foreigners. The different categories of financial regulation are summarized in a financial reform index that takes on values between zero (fully repressed) and 21 (fully liberalized). See Abiad, Detragiache and Tressel (2008) for a detailed discussion of the database. For 2006 and 2007, we use the values reported for 2005 .
} 
including it.

Financial market reforms may also have promoted the integration of money markets and caused real interest rates to converge across countries. Given that the risk-free rate is a component of the discount rate, differences in real interest rates should be associated with differences in valuations, thus possibly representing an important channel for EU membership to affect the segmentation measure. We obtain annual real interest rates from the World Bank, computed as the prime rate less current inflation as measured by the GDP deflator. For every country-pair, we calculate the absolute difference between the real interest rates. Of course, for the countries joining the Euro in 1999, nominal interest rate converged considerably (see Baele et al., 2004), but this may not have necessarily led to a full integration of real rates. Including this real interest rate channel in specification 3 reduces the EU effect by about $9 \%$ in case of the balanced sample and again by about $20 \%$ in case of the full sample.

In specification 4, we augment our set of channel variables with bilateral foreign direct investment (FDI) positions, available from 1994 on and hence only included in case of the full sample. The EU effect is now reduced by $37 \%$ and no longer statistically significant.

Finally, we also examine bilateral data on foreign residents, i.e. the relative amount of citizens from one country living in the other country. In this case, the size of the EU effect is reduced by about $15 \%$ for the balanced sample and by about $36 \%$ for the unbalanced sample.

The various specifications with different sample sizes show that, in all cases, the proposed channels reduced, but did not completely eliminate the EU effect. It is possible that there was an EU effect that is larger than the "sum of the parts." Alternatively, we are simply missing a few important channels, or measurement error in the channel variables we do use prevent them from fully driving out the EU effect. It remains striking that for all these different sample variations the EU effect was nearly always statistically significantly negative. 


\section{The Euro Crisis and Integration}

Since the end of 2007, Europe has experienced a global financial crisis and then severe sovereign debt and banking crises in the so-called GIIPS countries ${ }^{21}$ Our results show that EU harmonization and integration efforts led to significantly lower segmentation between EU member states than non-member states until 2007. This finding holds when explicitly controlling for the introduction of the Euro, which by 2007 had not contributed to the increased equity market integration in Europe. Our results imply that policy makers should be particularly concerned with preserving "EU institutions" so that the current Euro crisis does not endanger past accomplishments of economic and financial integration.

But has the current crisis already "undone" the integration benefits the EU countries experienced before 2007? In Bekaert et al. (2011), we show that segmentation is decreasing in measures of capital market openness and increasing in political risk and global risk aversion. Since 2007, the world and Europe in particular, has witnessed changing banking rules that "localize" banking sectors as well as steep increases in sovereign risk and overall political uncertainty. Risk aversion as measured by popular indices such as the VIX has at times peaked at unprecedented levels. It is possible that the associated increase in segmentation has affected the long-run integration benefits of EU membership.

We provide an analysis of the crisis using data through July 2012 covering the same country-pairs as the balanced sample above. There are two main differences with these data compared to our pre-crisis data. First, we analyze monthly rather than annual data. This allows us to extend the sample through the tumultuous months of 2012, rather than ending the sample in 2011. Second, we use Datastream's pre-calculated industry indices ${ }^{22}$ Our pre-crisis analysis constructed indices from the bottom up. Building industry portfolios from individual firms allowed us to cover smaller, mainly Eastern European countries where there are no Datastream indices. In addition, we know the firms that make up our portfolios at any point in time. With the Datastream indices, we only know the most recent index constituents as Datastream does not provide a time series of the composition of its indices.

\footnotetext{
${ }^{21}$ The GIIPS countries are Greece, Ireland, Italy, Portugal, and Spain.

${ }^{22}$ In a few cases, index coverage by Datastream begins after firm-level coverage, so that we are missing a small number of observations (506 observations or $1.6 \%$ of the expected sample size without missing observations) between 1990 and February 1992. Starting in March 1992, the data-set is fully balanced.
} 
This last point is important because our pre-crisis analysis includes controls for the number of firms in each industry portfolio as well as robustness analysis that only considers industry portfolios with at least five firms. While the Datastream index data allow us to verify our main results (using readily available index data) and to extend our sample period to the current crisis through July 2012, we do not have time series data on the number of firms included in the Datastream indices. We therefore use the corresponding variable from our firm-level based data set ${ }^{23}$ All other control variables have been updated ${ }^{24}$

In the first two columns of Table 9, we first show the monthly results for the 1990-2007 sample period to compare with the annual results in Tables 2 and 5 . The main results remain intact, constituting another robustness check of our main results. The EU effect is a bit stronger than the result in Table 2 and not too far from the finding in Table 5 where we restricted the sample to industries with a least five firms to minimize measurement error. We do find a small, but now significantly positive Euro effect, which is not surprising given the positive Euro effects shown before in Tables 4 and 5 .

The second part of Table 9 (columns 3 and 4) adds the crisis data from 2008 to 2012. The EU effect as well as the Euro effect remain essentially unchanged. These regressions indicate that, even when accounting for the recent crisis, the combined effect of EU membership and Euro adoption still leads to lower segmentation (about 110 basis points), but that EU members that have adopted the Euro are not more integrated. We also split the indicator variables by pre-crisis and post crisis (untabulated). The EU effect has weakened since 2007 (by about 70 or 80 basis points depending on whether the Euro indicator is included or not), but remains statistically significantly different from zero.

Extending our data through July 2012, our main results are robust: EU membership is important for economic and financial integration, while there is no evidence the introduction of a common currency has had a positive impact on integration. Both our novel measure of integration and our results may be relevant for the important decisions facing policy makers as well as for the future research that will analyze their actions.

\footnotetext{
${ }^{23}$ Since our firm level data set ends in 2007, we use the December 2007 values for January 2008 through July 2012.

${ }^{24}$ We measure earnings growth and return volatility using Datastream's index data. Leverage data have been updated again using Bureau van Dijk's OSIRIS database. For 2012, we use the 2011 leverage values.
} 


\section{Conclusions}

We provide a comprehensive approach to measure financial and economic integration among European countries and to study the effect of joint EU membership on bilateral segmentation. Our measure is based on average industry earnings yield differences and the assumption that, in financially as well as economically integrated markets, industry yields converge. Our main result reveals that between 1990 and 2007 bilateral earnings yield differences were between 80 and 140 basis points lower if both countries were EU members. EU membership significantly lowered both discount rate differentials across countries (financial integration) as well as expected earnings growth rate differentials (economic integration).

The independent EU effect survives in an instrumental variables analysis, where we use the distance to Brussels as an instrument for EU membership. We examine several channels through which EU membership could affect equity market integration, but find that they cannot fully account for the EU effect. While a number of interpretations are possible, it is conceivable that there was an independent EU effect that cannot be attributed to a particular measurable channel.

Importantly, we find that EU membership, but not Euro adoption increased financial and economic integration between European countries. That is, equity market segmentation decreased whether or not members have also adopted the Euro. Extending our sample period through July 2012 does not alter our main finding that EU membership increases integration, while Euro adoption does not. 


\section{References}

Abiad, A., Detragiache, E. and Tressel, T. (2008). A new database of financial reforms. IMF Working Paper.

Adjaouté, K. and Danthine, J.-P. (2004). Equity Returns and Integration: Is Europe Changing?, Oxford Review of Economic Policy 20(4): 555-570.

Alesina, A. F., Ardagna, S. and Galasso, V. (2008). The Euro and Structural Reforms. Working Paper, SSRN.

Aviat, A. and Coeurdacier, N. (2007). The geography of trade in goods and asset holdings, Journal of International Economics 71(1): 22 - 51.

Baele, L. (2005). Volatility spillover effects in European equity markets, Journal of Financial and Quantitative Analysis 40(02): 373-401.

Baele, L., Ferrando, A., Hordahl, P., Krylova, E. and Monnet, C. (2004). Measuring European financial integration, Oxford Review of Economic Policy 20(4): 509-530.

Barro, R. and Tenreyro, S. (2007). Economic effects of currency unions, Economic Inquiry 45(1): 1-23.

Bartram, S. M. and Wang, Y.-H. (2011). European financial market integration in the wake of the sovereign debt crisis: An industry analysis. Working Paper, SSRN.

Bekaert, G. (1995). Market integration and investment barriers in emerging equity markets, World Bank Economic Review 9(1): 75-107.

Bekaert, G. and Harvey, C. (1995). Time-varying world market integration, Journal of Finance 50(2): 403-444.

Bekaert, G., Harvey, C. R., Lundblad, C. T. and Siegel, S. (2011). What segments equity markets?, Review of Financial Studies 24(12): 3841-3890.

Bekaert, G., Hodrick, R. and Zhang, X. (2009). International stock return comovements, Journal of Finance 64(6): 2591-2626.

Berezin, M. and Diez-Medrano, J. (2008). Distance matters: Place, political legitimacy and popular support for European integration, Comparative European Politics 6: 1-32.

Bertrand, M., Duflo, E. and Mullainathan, S. (2004). How much should we trust differencesin-differences estimates?, Quarterly Journal of Economics 119(1): 249-275.

Blanchard, O. and Giavazzi, F. (2002). Current account deficits in the euro area: the end of the Feldstein-Horioka puzzle?, Brookings Papers on Economic Activity pp. 147-210.

Bris, A., Koskinen, Y. and Nilsson, M. (2008). The Euro and Corporate Valuations, Review of Financial Studies 22(8): 3171-3209. 
Cameron, A., Gelbach, J. and Miller, D. (2006). Robust inference with multi-way clustering. Working Paper, SSRN.

Cappiello, L., Kadareja, A. and Manganelli, S. (2010). The impact of the euro on equity markets, Journal of Financial and Quantitative Analysis 45(02): 473-502.

Chan, K., Covrig, V. and Ng, L. (2005). What determines the domestic bias and foreign bias? Evidence from mutual fund equity allocations worldwide, Journal of Finance 60(3): 1495-1534.

Edison, H. J. and Warnock, F. E. (2003). A simple measure of the intensity of capital controls, Journal of Empirical Finance 10(1-2): 81-103.

Engel, C. and Rogers, J. H. (2004). European product market integration after the euro, Economic Policy 19(39): 347-384.

Fischer, S., Sahay, R. and Gramont, C. A. V. (1998). How Far is Eastern Europe from Brussels? Working Paper, SSRN.

Frankel, J. (2005). Comments on Richard Baldwins "The Euros Trade Effects. Working Paper, Harvard University.

Frankel, J. A. and Rose, A. K. (1998). The endogenity of the optimum currency area criteria, The Economic Journal 108: 1009-1025.

Fratzscher, M. (2002). Financial Market Integration in Europe: On the Effects of EMU on Stock Markets, International Journal of Finance $\&$ Economics 7(3): 165-193.

Glick, R. and Rose, A. (2002). Does a currency union affect trade? The time-series evidence, European Economic Review 46(6): 1125-1151.

Goldberg, P. K. and Verboven, F. (2005). Market integration and convergence to the law of one price: evidence from the european car market, Journal of International Economics 65(1): 49-73.

Guiso, L., Jappelli, T., Padula, M., Pagano, M., Martin, P. and Gourinchas, P.-O. (2004). Financial market integration and economic growth in the eu, Economic Policy 19(40): $525-577$.

Hardouvelis, G., Malliaropulos, D. and Priestley, R. (2006). EMU and European Stock Market Integration, Journal of Business 79(1): 365-392.

Hardouvelis, G., Malliaropulos, D. and Priestley, R. (2007). The impact of EMU on the equity cost of capital, Journal of International Money and Finance 26(2): 305-327.

Jappelli, T. and Pagano, M. (2008). Financial market integration under EMU. Working Paper, SSRN. 
Kalemli-Ozcan, S., Papaioannou, E. and Peydró, J.-L. (2012). Financial Regulation, Financial Globalization and the Synchronization of Economic Activity. Journal of Finance, forthcoming.

Krueger, A. (2000). From Bismarck to Maastricht: The March to European Union and the Labor Compact, Labour Economics 7(2): 117-134.

Levine, R. and Zervos, S. (1998). Capital control liberalization and stock market development, World Development 26(7): 1169-1183.

Micco, A., Stein, E. and Ordoñez, G. (2003). The currency union effect on trade: early evidence from EMU, Economic Policy 18(37): 315-356.

Nicolaides, P. and Boean, S. R. (1996). The Process of Enlargement of the European Union, EIPASCOPE 3: 1-7.

Nicoletti, G., Haffner, R., Nickell, S., Scarpetta, S. and Zoega, G. (2001). Welfare and Employment in a United Europe, MIT Press, chapter European Integration, Liberalization, and Labor-Market Performance, pp. 147-235.

Portes, R. and Rey, H. (2005). The determinants of cross-border equity flows, Journal of International Economics 65(2): 269-296.

Santos Silva, J. and Tenreyro, S. (2010). Currency Unions in Prospect and Retrospect, Annual Review of Economics 2: 51-74.

Staiger, D. and Stock, J. (1997). Instrumental variables regression with weak instruments, Econometrica 65(3): 557-586.

Thompson, S. (2009). Simple formulas for standard errors that cluster by both firm and time. Working Paper, SSRN. 
Table 1

Countries, Sample Composition, EU Membership, and Euro Adoption

$1990-2007$

\begin{tabular}{|c|c|c|c|c|c|c|}
\hline \multirow[b]{2}{*}{ Country } & \multirow{2}{*}{$\begin{array}{l}\text { First } \\
\text { Year }\end{array}$} & \multirow{2}{*}{$\begin{array}{c}\text { Balanced } \\
\text { Sample }\end{array}$} & \multirow{2}{*}{$\begin{array}{l}\text { Core } \\
\text { Europe }\end{array}$} & \multirow{2}{*}{$\begin{array}{l}\text { Eastern } \\
\text { European }\end{array}$} & \multicolumn{2}{|c|}{$\begin{array}{c}\text { First Year of } \\
\text { Membership / Adoption }\end{array}$} \\
\hline & & & & & EU & Euro \\
\hline Austria & 1990 & $\mathbf{x}$ & & & 1995 & 1999 \\
\hline Belgium & 1990 & $\mathbf{x}$ & $\mathbf{x}$ & & 1957 & 1999 \\
\hline Bulgaria & 2003 & & & $\mathrm{X}$ & 2007 & - \\
\hline Croatia & 1999 & & & $\mathrm{X}$ & - & - \\
\hline Cyprus & 1995 & & & & 2004 & $2008^{\star}$ \\
\hline Czech Republic & 1995 & & & $\mathbf{x}$ & 2004 & - \\
\hline Denmark & 1990 & $x$ & $x$ & & 1973 & - \\
\hline Estonia & 2000 & & & $x$ & 2004 & $2011^{\star}$ \\
\hline Finland & 1990 & $x$ & & & 1995 & 1999 \\
\hline France & 1990 & $x$ & $x$ & & 1957 & 1999 \\
\hline Germany & 1990 & $x$ & $x$ & & 1957 & 1999 \\
\hline Greece & 1990 & $x$ & & & 1981 & 2001 \\
\hline Hungary & 1993 & & & $x$ & 2004 & - \\
\hline Iceland & 2005 & & & & - & - \\
\hline Ireland & 1990 & $x$ & $x$ & & 1973 & 1999 \\
\hline Italy & 1990 & $x$ & $x$ & & 1957 & 1999 \\
\hline Latvia & 2000 & & & $x$ & 2004 & - \\
\hline Lithuania & 2001 & & & $x$ & 2004 & - \\
\hline Luxembourg & 1991 & & $x$ & & 1957 & 1999 \\
\hline Malta & 2002 & & & & 2004 & $2008^{\star}$ \\
\hline Netherlands & 1990 & $x$ & $x$ & & 1957 & 1999 \\
\hline Norway & 1990 & $x$ & & & - & - \\
\hline Poland & 1994 & & & $x$ & 2004 & - \\
\hline Portugal & 1990 & $x$ & & & 1986 & 1999 \\
\hline Romania & 2000 & & & $x$ & 2007 & - \\
\hline Russian Federation & 1997 & & & $x$ & - & - \\
\hline Slovak Republic & 2001 & & & $x$ & 2004 & $2009^{*}$ \\
\hline Slovenia & 2001 & & & $\mathbf{x}$ & 2004 & 2007 \\
\hline Spain & 1990 & $\mathbf{x}$ & & & 1986 & 1999 \\
\hline Sweden & 1990 & $\mathbf{x}$ & & & 1995 & - \\
\hline Switzerland & 1990 & $x$ & & & - & - \\
\hline Turkey & 1992 & & & & - & - \\
\hline United Kingdom & 1990 & $x$ & $x$ & & 1973 & - \\
\hline Total countries & 33 & 16 & 9 & 12 & 27 & 13 \\
\hline Total distinct country pairs & 528 & 120 & & & 351 & 78 \\
\hline
\end{tabular}

This table reports for each country the first year that the country is included in our data set, whether we include the country in the Balanced Sample, whether we classify the country as a Core European or Eastern European country as well as the first year of EU membership and Euro adoption. * denotes Euro adoption after the end of the sample period. 
Table 2

EU Impact on Financial and Economic Segmentation in Europe

Balanced Sample: 1990 - 2007 ( $N=2,160$; Annual Frequency)

\begin{tabular}{|c|c|c|c|c|}
\hline & \multicolumn{4}{|c|}{ Dependent Variable: SEG } \\
\hline & 1 & 2 & 3 & 4 \\
\hline \multirow[t]{2}{*}{ EU - Indicator } & -0.0098 & -0.0159 & -0.0101 & -0.0143 \\
\hline & $(0.0038)$ & $(0.0045)$ & $(0.0029)$ & $(0.0045)$ \\
\hline \multirow[t]{2}{*}{ Sum of Number of Listed Firms (In) } & -0.0043 & -0.0033 & -0.0033 & -0.0108 \\
\hline & $(0.0011)$ & $(0.0010)$ & $(0.0010)$ & $(0.0057)$ \\
\hline \multirow[t]{2}{*}{ Abs. Diff. in Leverage } & 0.0597 & 0.0462 & 0.0755 & 0.0268 \\
\hline & $(0.0333)$ & $(0.0292)$ & $(0.0259)$ & $(0.0247)$ \\
\hline \multirow[t]{2}{*}{ Abs. Diff. in Ln Earnings Growth Volatility } & 0.0733 & 0.0624 & 0.0540 & 0.0620 \\
\hline & $(0.0509)$ & $(0.0469)$ & $(0.0369)$ & $(0.0398)$ \\
\hline \multirow[t]{2}{*}{ Abs. Diff. in Return Volatility } & 0.1241 & 0.0333 & 0.1004 & 0.0222 \\
\hline & $(0.1479)$ & $(0.1340)$ & $(0.0954)$ & $(0.1307)$ \\
\hline \multirow[t]{2}{*}{ Abs. Diff. in PC GDP in 1990 (in 1,000 USD) } & & -0.0009 & -0.0006 & \\
\hline & & $(0.0003)$ & $(0.0002)$ & \\
\hline \multirow[t]{2}{*}{ Distance (in 1,000 km) } & & 0.0065 & 0.0055 & \\
\hline & & $(0.0018)$ & $(0.0018)$ & \\
\hline \multirow[t]{2}{*}{ Common Language Indicator } & & -0.0025 & -0.0019 & \\
\hline & & $(0.0028)$ & $(0.0025)$ & \\
\hline \multirow[t]{2}{*}{ Abs. EY - Differential: Core Europe vs. USA } & & & 1.5082 & \\
\hline & & & $(0.2759)$ & \\
\hline \multirow[t]{2}{*}{ Core Europe - Earnings Yield } & & & 0.3094 & \\
\hline & & & $(0.0975)$ & \\
\hline Year Fixed Effects & No & No & No & Yes \\
\hline Country-pair Fixed Effects & No & No & No & Yes \\
\hline Adj. $R^{2}$ & 0.12 & 0.18 & 0.33 & 0.47 \\
\hline
\end{tabular}

This table reports coefficient estimates and standard errors for linear regression models of pairwise segmentation (SEG). All variables are defined in Appendix Table 2. All standard errors are robust to heteroskedasticity and to arbitrary correlation across country-pairs in a given year as well as across years for a given country-pair. Specification 4 contains year and country-pair fixed effects. Coefficient estimates with absolute $t$-statistics larger than 1.96 appear in bold. $N$ denotes the number of observations. 
Table 3

EU Impact on Differences in Discount Rates and Expected Earnings Growth

Balanced Sample: 1990 - 2007 ( $N=1,962$; Annual Frequency)

Differences in Discount Rates $\left(S E G^{D R}\right)$

EU - Indicator

Sum of Number of Listed Firms (In)

Abs. Diff. in Leverage

Abs. Diff. in Ln Earnings Growth Volatility

Abs. Diff. in Return Volatility

Abs. Diff. in PC GDP in 1990 (in 1,000 USD)

Distance (in 1,000 km)

Common Language Indicator

Abs. EY - Differential: Core Europe vs. USA

Core Europe - Earnings Yield

\begin{tabular}{lcccc} 
& & & \multicolumn{2}{c}{$(0.1369)$} \\
\hline Year Fixed Effects & No & No & No & Yes \\
Country-pair Fixed Effects & No & No & No & Yes \\
\hline Adj. $R^{2}$ & 0.37 & 0.37 & 0.43 & 0.49
\end{tabular}

Differences in Expected Earnings Growth Rates $\left(S E G^{G O}\right)$

\begin{tabular}{|c|c|c|c|}
\hline 1 & 2 & 3 & 4 \\
\hline $\begin{array}{c}-\mathbf{0 . 0 1 3 5} \\
(0.0055)\end{array}$ & $\begin{array}{r}-0.0207 \\
(0.0069)\end{array}$ & $\begin{array}{c}-\mathbf{0 . 0 1 7 4} \\
(0.0067)\end{array}$ & $\begin{array}{c}-\mathbf{0 . 0 3 9 8} \\
(0.0114)\end{array}$ \\
\hline $\begin{array}{c}-\mathbf{0 . 0 0 3 5} \\
(0.0014)\end{array}$ & $\begin{array}{c}-0.0009 \\
(0.0014)\end{array}$ & $\begin{array}{c}-0.0004 \\
(0.0014)\end{array}$ & $\begin{array}{l}0.0030 \\
(0.0042)\end{array}$ \\
\hline $\begin{array}{c}-0.0023 \\
(0.0673)\end{array}$ & $\begin{array}{c}-0.0229 \\
(0.0644)\end{array}$ & $\begin{array}{c}-0.0003 \\
(0.0628)\end{array}$ & $\begin{array}{l}0.0285 \\
(0.0495)\end{array}$ \\
\hline $\begin{array}{l}0.0941 \\
(0.0532)\end{array}$ & $\begin{array}{l}0.0849 \\
(0.0503)\end{array}$ & $\begin{array}{l}0.0764 \\
(0.0458)\end{array}$ & $\begin{array}{l}0.0821 \\
(0.0455)\end{array}$ \\
\hline \multirow[t]{6}{*}{$\begin{array}{l}\mathbf{0 . 4 1 7 1} \\
(0.1890)\end{array}$} & $\begin{array}{l}0.2306 \\
(0.1977)\end{array}$ & $\begin{array}{l}0.2479 \\
(0.1905)\end{array}$ & $\begin{array}{c}-0.3110 \\
(0.2445)\end{array}$ \\
\hline & $\begin{array}{c}-0.0006 \\
(0.0005)\end{array}$ & $\begin{array}{c}-0.0005 \\
(0.0005)\end{array}$ & \\
\hline & $\begin{array}{l}\mathbf{0 . 0 0 9 9} \\
(0.0029)\end{array}$ & $\begin{array}{l}\mathbf{0 . 0 1 0 5} \\
(0.0029)\end{array}$ & \\
\hline & $\begin{array}{c}-0.0124 \\
(0.0045)\end{array}$ & $\begin{array}{r}-0.0117 \\
(0.0044)\end{array}$ & \\
\hline & & $\begin{array}{l}1.2059 \\
(0.4995)\end{array}$ & \\
\hline & & $\begin{array}{l}0.3113 \\
(0.1652)\end{array}$ & \\
\hline No & No & No & Yes \\
\hline No & No & No & Yes \\
\hline 0.05 & 0.09 & 0.12 & 0.27 \\
\hline
\end{tabular}

This table reports coefficient estimates and standard errors for linear regression models of pairwise absolute differences in estimated discount rates $\left(S E G^{D R}\right)$ and in estimated expected earnings growth $\left(S E G^{G O}\right)$. The dependent variables are obtained from GMM estimation of a system of three

equations. The sample size is smaller than for the regular balanced sample due to missing explanatory variables in the GMM estimation. All variables are defined in Appendix Table 2. All standard errors are robust to heteroskedasticity and to arbitrary correlation across country-pairs in a given year as well as across years for a given country-pair. Specification 4 contains in both cases year and country-pair fixed effects. Coefficient estimates with absolute $t$ statistics larger than 1.96 appear in bold. $N$ denotes the number of observations. 
Table 4

Segmentation, the EU, and the Euro

Balanced Sample: 1990 - 2007 ( $N=$ 2,160; Annual Frequency)

Panel A: The Euro

Dependent Variable: SEG

\begin{tabular}{lcccc} 
& 1 & 2 & 3 & 4 \\
\hline EU - Indicator & $-\mathbf{0 . 0 0 8 6}$ & $-\mathbf{0 . 0 1 4 5}$ & $\mathbf{- 0 . 0 0 9 7}$ & $\mathbf{- 0 . 0 1 4 5}$ \\
& $(0.0033)$ & $(0.0040$ & $(0.0029)$ & $(0.0045)$ \\
Euro - Indicator & -0.0033 & -0.0045 & -0.0017 & 0.0028 \\
& $(0.0030)$ & $(0.0032)$ & $(0.0020)$ & $(0.0030)$ \\
\hline Controls & & & & Yes \\
- Bias Controls & Yes & Yes & Yes & No \\
- Country-pair Controls & No & Yes & Yes & Yes \\
- Time-series Controls & No & No & No & Yes \\
Year Fixed Effects & No & No & No & Yes \\
Country-pair Fixed Effects & No & No & No & 0.47 \\
\hline Adj. $R^{2}$ & 0.13 & 0.18 & & \multirow{2}{*}{0.33} \\
\hline
\end{tabular}

Panel B: Exchange Rate Stability

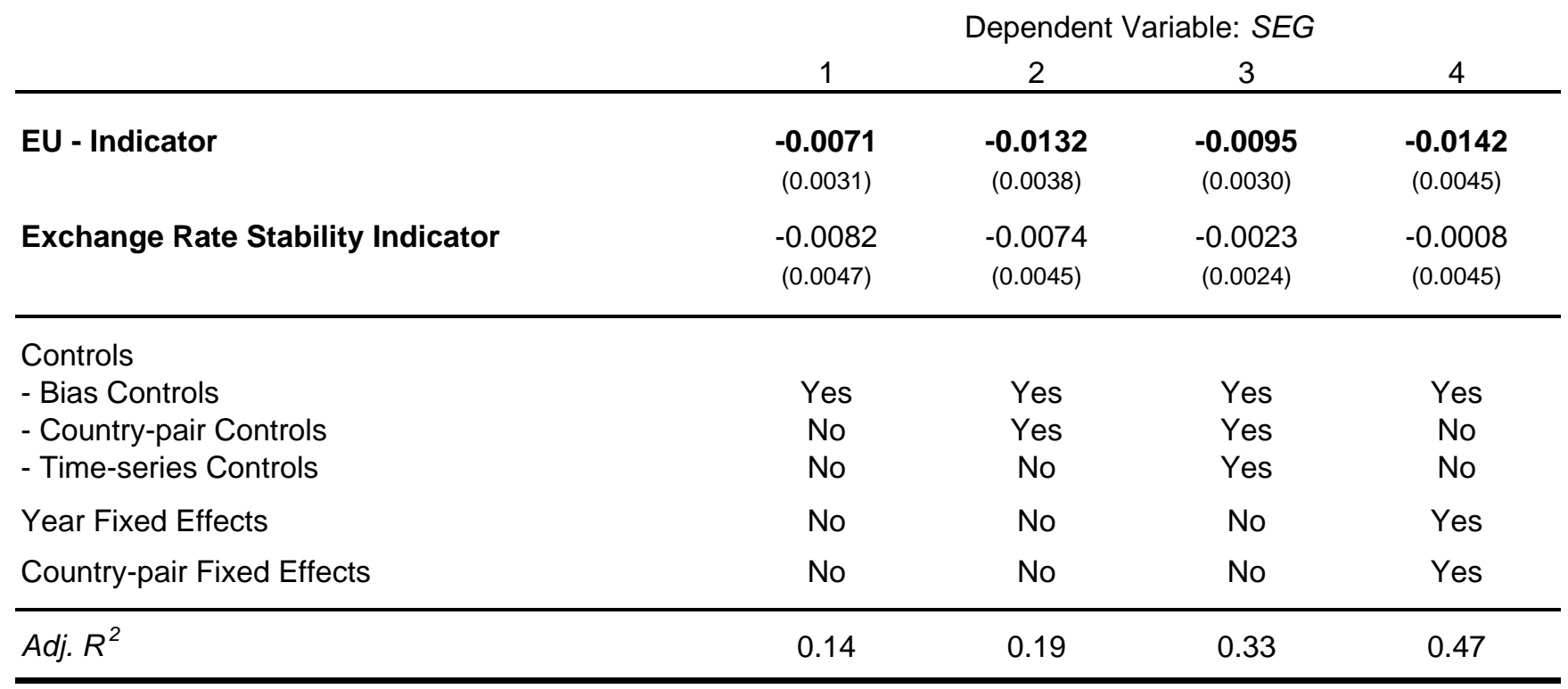

This table reports coefficient estimates and standard errors for linear regression models of pairwise segmentation. The Euro - Indicator equals one in a given year if both countries in a country-pair have adopted the Euro. It is zero in all other cases. The Exchange Rate Stability Indicator is based on a transformed measure of realized volatility. A country with zero exchange rate volatility (relative to the Deutscr Mark / Euro) takes on a value of one; a country with 1\% monthly volatility (roughly that of a major floating currency) would effectively receive a zero. For a country-pair, we employ the average value of the two countries in a pair. All variables are defined in Appendix Table 2. All standard errors are robust to heteroskedasticity and to arbitrary correlation across country-pairs in a given year as well as across years for a given country-pair. In each panel, specifications 1, through 4 contain the same control variables as the corresponding specifications in Table 2. Coefficient estimates with absolute $t$-statistics larger than 1.96 appear in bold. $N$ denotes the number of observations. 
Table 5

\section{Robustness}

Balanced Sample: 1990 - 2007, Annual Frequency

\begin{tabular}{|c|c|c|c|c|c|c|c|c|}
\hline No. & $\begin{array}{l}\text { Segmentation } \\
\text { Measure }\end{array}$ & $\begin{array}{l}\text { EU Specification } \\
\text { EU - Indicator }\end{array}$ & EU and Eur & $\begin{array}{l}\text { Specification } \\
\text { Euro - Indicator }\end{array}$ & $\begin{array}{c}\text { Bias } \\
\text { Controls } \\
\end{array}$ & $\begin{array}{c}\text { Year Fixed } \\
\text { Effects }\end{array}$ & $\begin{array}{l}\text { Country- } \\
\text { pair Fixed } \\
\text { Effects } \\
\end{array}$ & $N$ \\
\hline 1 & At least five Firms & $\begin{array}{l}-\mathbf{0 . 0 2 4 6} \\
(0.0084)\end{array}$ & $\begin{array}{c}-0.0250 \\
(0.0083)\end{array}$ & $\begin{array}{l}0.0037 \\
(0.0035)\end{array}$ & Yes & Yes & Yes & 2,145 \\
\hline 2 & Equally Weighted & $\begin{array}{c}-\mathbf{0 . 0 1 2 4} \\
(0.0042)\end{array}$ & $\begin{array}{l}-0.0125 \\
(0.0041)\end{array}$ & $\begin{array}{l}0.0013 \\
(0.0029)\end{array}$ & Yes & Yes & Yes & 2,145 \\
\hline 3 & $\ln (S E G)$ & $\begin{array}{c}-\mathbf{0 . 2 0 5 7} \\
(0.0660)\end{array}$ & $\begin{array}{c}-0.2099 \\
(0.0651)\end{array}$ & $\begin{array}{l}0.0508 \\
(0.0641)\end{array}$ & Yes & Yes & Yes & 2,160 \\
\hline
\end{tabular}

This table reports coefficient estimates and standard errors for linear regression models of pairwise segmentation (SEG). Pairwise segmentation is measured in three alternative ways: a measure for whose construction all industries with less than five firms per country and year have been excluded (1), an equally weighted average of absolute industry valuation differences for industries with at least five firms per country and year (2), and the natural log of the main segmentation measure (In(SEG) - (3)). We examine the effect of joint EU membership as well as the effect of joint EU membership controlling for joint Euro adoption. Bias control variables are the same as in Table 2 Specification 4. All specifications contain year and country-pair fixed effects. All variables are defined in Appendix Table 2. All standard errors are robust to heteroskedasticity and to arbitrary correlation across country-pairs in a given year as well as across years for a given country-pair. Coefficient estimates with absolute $t$-statistics larger than 1.96 appear in bold. $N$ denotes the number of observations. 
Table 6

Market Segmentation, Unbalanced Sample, and Robustness

Full Sample: 1990 - 2007, Annual Frequency

Panel A: EU Impact on Financial and Economic Segmentation in Europe $(N=5,665)$

\begin{tabular}{|c|c|c|c|c|}
\hline & 1 & 2 & 3 & 4 \\
\hline \multirow[t]{2}{*}{ EU - Indicator } & -0.0168 & -0.0139 & -0.0094 & -0.0084 \\
\hline & $(0.0034)$ & $(0.0027)$ & $(0.0027)$ & $(0.0040)$ \\
\hline \multirow[t]{2}{*}{ Sum of Number of Listed Firms (In) } & -0.0043 & -0.0017 & -0.0025 & -0.0028 \\
\hline & $(0.0014)$ & $(0.0011)$ & $(0.0011)$ & $(0.0042)$ \\
\hline \multirow[t]{2}{*}{ Abs. Diff. in Leverage } & 0.0647 & 0.0538 & 0.0522 & 0.0417 \\
\hline & $(0.0240)$ & $(0.0215)$ & $(0.0202)$ & $(0.0247)$ \\
\hline \multirow[t]{2}{*}{ Abs. Diff. in Ln Earnings Growth Volatility } & 0.0589 & 0.0512 & 0.0618 & 0.0688 \\
\hline & $(0.0369)$ & $(0.0350)$ & $(0.0331)$ & $(0.0232)$ \\
\hline \multirow[t]{2}{*}{ Abs. Diff. in Return Volatility } & 0.1770 & 0.1211 & 0.1216 & 0.2781 \\
\hline & $(0.0935)$ & $(0.0829)$ & $(0.0757)$ & $(0.1249)$ \\
\hline \multirow[t]{2}{*}{ Abs. Diff. in PC GDP in 1990 (in 1,000 USD) } & & 0.0001 & 0.0002 & \\
\hline & & $(0.0002)$ & $(0.0002)$ & \\
\hline \multirow[t]{2}{*}{ Distance (in 1,000 km) } & & 0.0032 & 0.0040 & \\
\hline & & $(0.0013)$ & $(0.0013)$ & \\
\hline \multirow[t]{2}{*}{ Common Language Indicator } & & 0.0015 & 0.0031 & \\
\hline & & $(0.0038)$ & $(0.0036)$ & \\
\hline \multirow[t]{2}{*}{ Eastern Europe Indicator } & & 0.0128 & 0.0164 & \\
\hline & & $(0.0050)$ & $(0.0047)$ & \\
\hline \multirow[t]{2}{*}{ Abs. EY - Differential: Core Europe vs. USA } & & & 1.8117 & \\
\hline & & & $(0.7096)$ & \\
\hline \multirow[t]{2}{*}{ Core Europe - Earnings Yield } & & & -0.1218 & \\
\hline & & & $(0.2766)$ & \\
\hline Year Fixed Effects & No & No & No & Yes \\
\hline Country-pair Fixed Effects & No & No & No & Yes \\
\hline Adj. $R^{2}$ & 0.12 & 0.14 & 0.17 & 0.38 \\
\hline
\end{tabular}

Panel B: Robustness

\begin{tabular}{|c|c|c|c|c|c|c|c|}
\hline No. & Segmentation Measure & $\begin{array}{c}\text { EU - } \\
\text { Indicator }\end{array}$ & $\begin{array}{c}\text { Bias } \\
\text { Controls } \\
\end{array}$ & $\begin{array}{c}\text { Year Fixed } \\
\text { Effects }\end{array}$ & $\begin{array}{c}\text { Country-pair } \\
\text { Fixed } \\
\text { Effects }\end{array}$ & Adj. $R^{2}$ & $N$ \\
\hline & At least five Firms & $\begin{array}{c}-\mathbf{0 . 0 1 3 5} \\
(0.0054)\end{array}$ & Yes & Yes & Yes & 0.36 & 3,918 \\
\hline 2 & Equally Weighted & $\begin{array}{c}-0.0094 \\
(0.0034)\end{array}$ & Yes & Yes & Yes & 0.40 & 3,918 \\
\hline 3 & $\ln (S E G)$ & $\begin{array}{c}-\mathbf{0 . 1 3 4 9} \\
(0.0597)\end{array}$ & Yes & Yes & Yes & 0.46 & 5,720 \\
\hline
\end{tabular}

This table reports coefficient estimates and standard errors for linear regression models of pairwise segmentation for the Unbalanced Sample. Panel A reports results for the main segmentation measure "SEG". Specification 4 contains year and country-pair fixed effects. Panel B reports robustness results using alternative constructions of the segmentation measure: a measure for whose construction all industries with less than five firms per country and year have been excluded (1), an equally weighted average of absolute industry valuation differences for industries with at least five firms per country and year (2), and the natural log of the main segmentation measure (In(SEG) (3)). All specifications in Panel B contain the same control variables as specification (4) in Panel A as well as year and country-pair fixed effects. All variables are defined in Appendix Table 2. All standard errors are robust to heteroskedasticity and to arbitrary correlation across country-pairs in a given year as well as across years for a given country-pair. Coefficient estimates with absolute $t$-statistics larger than 1.96 appear in bold. $N$ denotes the number of observations. 
Full Sample: 1990 - 2007 ( $N=5,665$; Annual Frequency)

\section{Panel A: Instrumental Variables Regression of Segmentation}

Dependent Variable

EU

SEG

Distance to Brussels (in $1000 \mathrm{~km}$ )

\section{EU - Indicator}

Sum of Number of Listed Firms (In)

Abs. Diff. in Leverage

Abs. Diff. in Ln Earnings Growth Volatility

Abs. Diff. in Return Volatility

Abs. Diff. in PC GDP in 1990 (in 1,000 USD)

Distance (in 1,000 km)

Common Language Indicator

Eastern Europe Indicator

\begin{tabular}{lcc} 
& $\begin{array}{c}-0.2752 \\
(0.0360)\end{array}$ & $\begin{array}{c}0.0072 \\
(0.0048)\end{array}$ \\
\hline Year Fixed Effects & Yes & Yes \\
\hline
\end{tabular}

\begin{tabular}{ll}
\hline Adj. $R^{2}$ & 0.36
\end{tabular}

Partial $R^{2}$

0.04

$F$ - test for weak instrument
Panel B: Bivariate Model of EU Membership and Segmentation

\begin{tabular}{|c|c|c|}
\hline & Deper & riable \\
\hline & $E U$ & SEG \\
\hline Distance to Brussels (in $1000 \mathrm{~km}$ ) & -0.2967 & \\
\hline & $(0.0463)$ & \\
\hline EU - Indicator & & -0.0253 \\
\hline & & $(0.0066)$ \\
\hline Sum of Number of Listed Firms (In) & & -0.0034 \\
\hline & & $(0.0010)$ \\
\hline Abs. Diff. in Leverage & & 0.0625 \\
\hline & & $(0.0189)$ \\
\hline Abs. Diff. in Ln Earnings Growth Volatility & & 0.0716 \\
\hline & & $(0.0328)$ \\
\hline Abs. Diff. in Return Volatility & & 0.0651 \\
\hline & & $(0.0714)$ \\
\hline Abs. Diff. in PC GDP in 1990 (in 1,000 USD) & -0.0205 & 0.0000 \\
\hline & $(0.0029)$ & $(0.0002)$ \\
\hline Distance (in 1,000 km) & 0.0296 & 0.0024 \\
\hline & $(0.0336)$ & $(0.0012)$ \\
\hline Common Language Indicator & -0.2142 & 0.0000 \\
\hline & $(0.0866)$ & $(0.0045)$ \\
\hline Eastern Europe Indicator & -0.4266 & 0.0098 \\
\hline & $(0.1097)$ & $(0.0033)$ \\
\hline Year Fixed Effects & Yes & Yes \\
\hline
\end{tabular}

This table reports coefficient estimates and standard errors for an instrumental variables (IV) regression of pairwise segmentation (Panel A) and for a bivariate model of pairwise EU membership (column "EU") and segmentation (column "SEG"). In Panel A, estimates for pairwise EU membership (column "EU") are from a linear probability model that is the first-stage regression of the IV regression. The partial $R^{2}$ reflects the contribution of the proposed instrument and the $F$ - test for weak instrument refers to the test that the coefficient of the instrument is zero (the approximate critical value for a rejection at the 5\% confidence level is 10). In Panel B, estimates for EU

membership (column "EU") represent marginal effects from a probit model that is jointly estimated with the segmentation equation. Marginal effects are calculated at the sample mean for continuous variables, but represent a discrete change for indicator variables. All variables are defined in Appendix Table 2 . All standard errors are robust to heteroskedasticity and to arbitrary correlation across country-pairs in a given year as well as across years for a given country-pair. All specifications contain year fixed effects. Coefficient estimates with absolute $t$-statistics larger than 1.96 appear in bold. $N$ denotes the number of observations. 
Table 8

Segmentation and the EU: Channels

\begin{tabular}{|c|c|c|c|c|c|c|}
\hline No. & $N$ & Sample & $\begin{array}{l}\text { EU - Indicator } \\
\text { w/o Channels }\end{array}$ & Channels & $\begin{array}{l}\text { EU - Indicator } \\
\text { w/ Channels }\end{array}$ & $\begin{array}{l}\text { Change of } \\
\text { EU-Indicator }\end{array}$ \\
\hline \multirow[t]{3}{*}{1} & 2,160 & Balanced & -0.0143 & \multirow[t]{3}{*}{ Trade, Equity Market, MCAP/GDP, Telecommunication } & -0.0137 & $-4.3 \%$ \\
\hline & \multirow[t]{2}{*}{5,665} & \multirow{2}{*}{ Full } & $\begin{array}{c}(0.0045) \\
-\mathbf{0 . 0 0 8 4}\end{array}$ & & $\begin{array}{c}(0.0044) \\
-0.0063\end{array}$ & $-24.6 \%$ \\
\hline & & & $(0.0040)$ & & $(0.0039)$ & \\
\hline \multirow[t]{4}{*}{2} & 2,160 & Balanced & -0.0143 & \multirow{4}{*}{$\begin{array}{l}\text { Trade, Equity Market, MCAP/GDP, Telecommunication, } \\
\text { Financial Reform }\end{array}$} & -0.0140 & $-1.9 \%$ \\
\hline & & & $(0.0045)$ & & $(0.0041)$ & \\
\hline & \multirow{2}{*}{4,146} & \multirow[t]{2}{*}{ Full } & -0.0118 & & -0.0093 & $-20.6 \%$ \\
\hline & & & $(0.0039)$ & & $(0.0051)$ & \\
\hline \multirow[t]{4}{*}{3} & 1,466 & Balanced & -0.0224 & \multirow{4}{*}{$\begin{array}{l}\text { Trade, Equity Market, MCAP/GDP, Telecommunication, } \\
\text { Absolute Real Interest Differential }\end{array}$} & -0.0204 & $-8.9 \%$ \\
\hline & & & $(0.0057)$ & & $(0.0057)$ & \\
\hline & \multirow[t]{2}{*}{3,504} & \multirow[t]{2}{*}{ Full } & -0.0093 & & -0.0075 & $-19.5 \%$ \\
\hline & & & $(0.0060)$ & & $(0.0064)$ & \\
\hline \multirow[t]{3}{*}{4} & NA & Balanced & NA & \multirow[t]{3}{*}{$\begin{array}{l}\text { Trade, Equity Market, MCAP/GDP, Telecommunication, } \\
\text { FDI }\end{array}$} & NA & NA \\
\hline & \multirow[t]{2}{*}{4,085} & \multirow[t]{2}{*}{ Full } & -0.0115 & & -0.0073 & $-36.8 \%$ \\
\hline & & & $(0.0051)$ & & $(0.0047)$ & \\
\hline \multirow[t]{4}{*}{5} & 324 & Balanced & -0.0274 & \multirow{4}{*}{$\begin{array}{l}\text { Trade, Equity Market, MCAP/GDP, Telecommunication, } \\
\text { Foreign Residents }\end{array}$} & -0.0234 & $-14.5 \%$ \\
\hline & & & $(0.0074)$ & & $(0.0080)$ & \\
\hline & \multirow{2}{*}{2,197} & \multirow[t]{2}{*}{ Full } & -0.0143 & & -0.0092 & $-35.7 \%$ \\
\hline & & & $(0.0051)$ & & $(0.0054)$ & \\
\hline
\end{tabular}

This table reports coefficient estimates and standard errors for regression models of pairwise segmentation for a balanced sample (i.e. including only country-pairs with complete data in 1990) and a full sample that employs all available observations. All specifications include: Sum of Number of Listed Firms (In), Abs. Diff. in Leverage, Abs. Diff. in Ln Earnings Growth Volatility, Abs. Diff. in Return Volatility as well as year and country-pair fixed effects. For each model, we first report the coefficient estimate of the EU-Indicator when the Channel variables are excluded. We then report the coefficient estimate of the EU-Indicator, when the listed Channel variables are included. Trade is the relative amount of bilateral trade between both countries in a pair. Equity Market refers to two variables: the average equity market openness across both countries in a pair as well as the absolute value of the difference in equity market

openness between them. MCAP/GDP refers to the average relative equity market capitalization as well as the absolute value of the openness between them. MCAP/GDP refers to the average relative equity market capitalization as well as the absolute value of the
difference between both countries. Telecommunication refers to the average telecommunication coverage as well as the absolute value of the difference between both countries. Financial Reform refers to the average as well as difference in financial reform orientation. Absolute real interest differential refers to the absolute value of the difference in real interest rates between both countries. FDI refers to the relative amount of the bilateral FDI holdings. Foreign Residents refers to the relative amount of citizens from one country living in the other country. All variables are defined in Appendix Table 2. All standard errors are robust to heteroskedasticity and to arbitrary correlation across country-pairs in a given year as well as across years for a given country-pair. Coefficient estimates with absolute $t$ statistics larger than 1.96 appear in bold. We also report the relative change of the coefficient estimate of the EU-Indicator. $N$ denotes the number of observations. 
Table 9

The Euro Crisis and Market Integration

Monthly Frequency: January 1990 - July 2012

\begin{tabular}{|c|c|c|c|c|}
\hline \multirow[b]{2}{*}{ VARIABLES } & \multicolumn{2}{|c|}{ Pre-Crisis: 1990 - 2007} & \multicolumn{2}{|c|}{ Full Sample: 1990 - 2012} \\
\hline & 1 & 2 & 3 & 4 \\
\hline \multirow[t]{2}{*}{ EU - Indicator } & -0.0177 & -0.0182 & -0.0173 & -0.0180 \\
\hline & $(0.0048)$ & $(0.0048)$ & $(0.0047)$ & $(0.0046)$ \\
\hline \multirow{2}{*}{ Euro - Indicator } & & 0.0066 & & 0.0070 \\
\hline & & $(0.0023)$ & & $(0.0023)$ \\
\hline \multirow{2}{*}{ Sum of Number of Listed Firms (In) } & -0.0113 & -0.0120 & -0.0150 & -0.0149 \\
\hline & $(0.0056)$ & $(0.0055)$ & $(0.0050)$ & $(0.0048)$ \\
\hline \multirow[t]{2}{*}{ Abs. Diff. in Leverage } & 0.0266 & 0.0204 & 0.0534 & 0.0489 \\
\hline & $(0.0192)$ & $(0.0196)$ & $(0.0186)$ & $(0.0184)$ \\
\hline \multirow[t]{2}{*}{ Abs. Diff. in Ln Earnings Growth Volatility } & 0.0231 & 0.0179 & 0.0494 & 0.0448 \\
\hline & $(0.0208)$ & $(0.0200)$ & $(0.0176)$ & $(0.0170)$ \\
\hline \multirow[t]{2}{*}{ Abs. Diff. in Return Volatility } & 0.0952 & 0.0942 & 0.1143 & 0.1254 \\
\hline & $(0.0816)$ & $(0.0829)$ & $(0.0784)$ & $(0.0786)$ \\
\hline Month Fixed Effects & Yes & Yes & Yes & Yes \\
\hline Country-pair Fixed Effects & Yes & Yes & Yes & Yes \\
\hline$N$ & 25,414 & 25,414 & 32,014 & 32,014 \\
\hline Adj. $R^{2}$ & 0.405 & 0.410 & 0.434 & 0.439 \\
\hline
\end{tabular}

This table reports coefficient estimates and standard errors for linear regression models of pairwise segmentation (SEG). The segmentation measure as well as the earnings growth and return volatility controls are constructed for all country-pairs in the balanced sample, using Datastream industry index data at the monthly frequency. In a few cases, index coverage by Datastream begins after firm-level coverage, so that for a few country-pairs we are missing a small number of observations (506 observations or $1.6 \%$ of the expected sample size without missing observations) between 1990 and February 1992. Starting in March 1992, the data-set is fully balanced. All other variables are defined in Appendix Table 2. The Number of Listed Firms is obtained from our main, firm-level data set, since Datastream does not provide the historical composition of the industry indices used for this table. For 2008 through July 2012, we use the December 2007 values for the Number of Listed Firms. All standard errors are robust to heteroskedasticity and to arbitrary correlation across country-pairs in a given year as well as across years for a given country-pair. All specifications contain year and country-pair fixed effects. Coefficient estimates with absolute $t$ statistics larger than 1.96 appear in bold. $N$ denotes the number of observations. 
Figure 1

Benchmarking Segmentation

Full Sample: 1990 - 2007, Annual Frequency

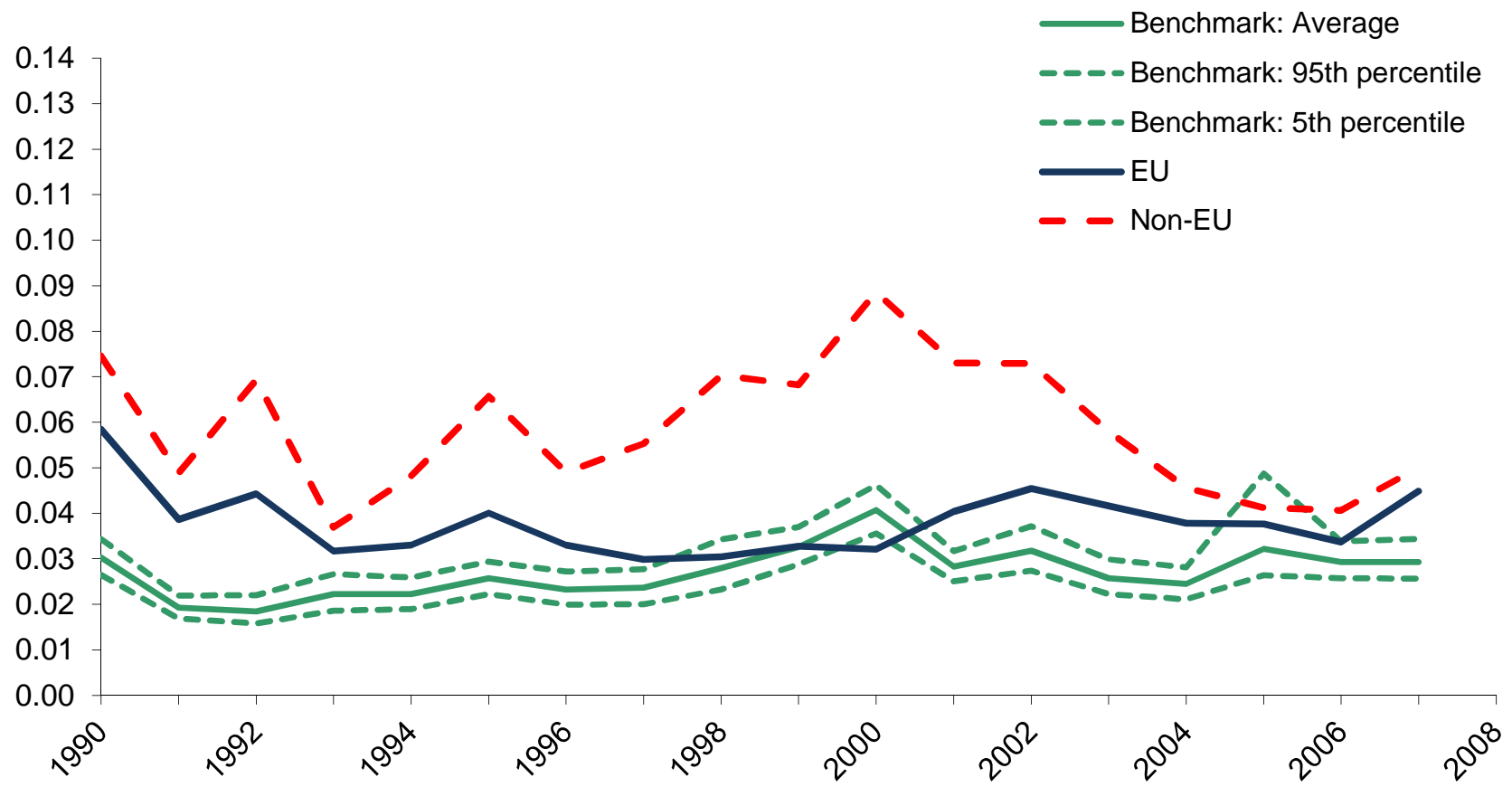

This figure presents average bilateral segmentation between 1990 and 2007 for all EU and Non-EU country pairs. For comparison, the figure shows the average U.S. benchmark segmentations level (constructed for the set of all European countries) together with a 90\% confidence interval. 
Appendix Table 1

Summary Statistics

Panel A: Full Sample

\begin{tabular}{|c|c|c|c|c|c|c|c|}
\hline \multirow[b]{2}{*}{ Variable } & \multirow[b]{2}{*}{$\mathrm{N}$} & \multirow[b]{2}{*}{ Mean } & \multirow[b]{2}{*}{ Std. Dev. } & \multirow[b]{2}{*}{ Min } & \multirow[b]{2}{*}{ Max } & \multicolumn{2}{|c|}{ Conditional Mean } \\
\hline & & & & & & $E U=0$ & $\mathrm{EU}=1$ \\
\hline Pairwise Segmentation & 5,665 & 0.0506 & 0.0369 & 0.0000 & 0.3506 & 0.0602 & 0.0380 \\
\hline EU - Indicator & 5,665 & 0.4342 & 0.4957 & 0.0000 & 1.0000 & 0.0000 & 1.0000 \\
\hline Distance to Brussels (in $1000 \mathrm{~km}$ ) & 5,665 & 1.5226 & 0.6224 & 0.1730 & 2.9050 & 1.6513 & 1.3548 \\
\hline Sum of number of listed firms (In) & 5,665 & 5.2427 & 1.2270 & 0.6931 & 7.7803 & 5.0115 & 5.5439 \\
\hline Abs. Diff. in Leverage & 5,665 & 0.0837 & 0.0387 & 0.0010 & 0.4813 & 0.0873 & 0.0790 \\
\hline Abs. Diff. in Ln Earnings Growth Volatility & 5,665 & 0.0979 & 0.0429 & 0.0008 & 0.3729 & 0.1028 & 0.0914 \\
\hline Abs. Diff. in Return Volatility & 5,665 & 0.0279 & 0.0161 & 0.0003 & 0.1036 & 0.0326 & 0.0219 \\
\hline Abs. Diff. in PC GDP in 1990 (in 1,000 USD) & 5,665 & 10.3068 & 7.6038 & 0.0100 & 31.3100 & 12.2012 & 7.8388 \\
\hline Distance (in 1,000 km) & 5,665 & 1.4663 & 0.7750 & 0.0596 & 4.8821 & 1.5417 & 1.3682 \\
\hline Common Language Indicator & 5,665 & 0.0572 & 0.2322 & 0.0000 & 1.0000 & 0.0456 & 0.0724 \\
\hline Eastern Europe Indicator & 5,665 & 0.4613 & 0.4985 & 0.0000 & 1.0000 & 0.6009 & 0.2793 \\
\hline Abs. EY - Differential: Core Europe vs. USA & 5,665 & 0.0146 & 0.0037 & 0.0104 & 0.0263 & 0.0151 & 0.0140 \\
\hline Core Europe - Earnings Yield & 5,665 & 0.0591 & 0.0122 & 0.0189 & 0.0875 & 0.0576 & 0.0611 \\
\hline
\end{tabular}

\section{Panel B: Balanced Sample}

\begin{tabular}{|c|c|c|c|c|c|c|c|}
\hline \multirow[b]{2}{*}{ Variable } & \multirow[b]{2}{*}{$\mathrm{N}$} & \multirow[b]{2}{*}{ Mean } & \multirow[b]{2}{*}{ Std. Dev. } & \multirow[b]{2}{*}{ Min } & \multirow[b]{2}{*}{ Max } & \multicolumn{2}{|c|}{ Conditional Mean } \\
\hline & & & & & & $E U=0$ & $E U=1$ \\
\hline Pairwise Segmentation & 2,160 & 0.0380 & 0.0207 & 0.0095 & 0.2140 & 0.0461 & 0.0342 \\
\hline EU - Indicator & 2,160 & 0.6750 & 0.4685 & 0.0000 & 1.0000 & 0.0000 & 1.0000 \\
\hline Euro - Indicator & 2,160 & 0.2199 & 0.4143 & 0.0000 & 1.0000 & 0.0000 & 0.3258 \\
\hline Exchange Rate Stability Indicator & 2,160 & 0.3838 & 0.3929 & 0.0000 & 1.0000 & 0.1722 & 0.4857 \\
\hline Sum of number of listed firms (In) & 2,160 & 6.0990 & 0.7353 & 4.3307 & 7.7803 & 5.9186 & 6.1858 \\
\hline Abs. Diff. in Leverage & 2,160 & 0.0846 & 0.0286 & 0.0084 & 0.3255 & 0.0899 & 0.0820 \\
\hline Abs. Diff. in Ln Earnings Growth Volatility & 2,160 & 0.0908 & 0.0294 & 0.0139 & 0.2475 & 0.0932 & 0.0897 \\
\hline Abs. Diff. in Return Volatility & 2,160 & 0.0213 & 0.0096 & 0.0031 & 0.0646 & 0.0228 & 0.0206 \\
\hline Abs. Diff. in PC GDP in 1990 (in 1,000 USD) & 2,160 & 6.9806 & 5.3275 & 0.0419 & 24.4676 & 10.5867 & 5.2443 \\
\hline Distance (in 1,000 km) & 2,160 & 1.3585 & 0.7100 & 0.1730 & 3.3630 & 1.3143 & 1.3797 \\
\hline Common Language Indicator & 2,160 & 0.1000 & 0.3001 & 0.0000 & 1.0000 & 0.1496 & 0.0761 \\
\hline Abs. EY - Differential: Core Europe vs. USA & 2,160 & 0.0160 & 0.0046 & 0.0104 & 0.0263 & 0.0176 & 0.0152 \\
\hline Core Europe - Earnings Yield & 2,160 & 0.0580 & 0.0148 & 0.0189 & 0.0875 & 0.0586 & 0.0577 \\
\hline
\end{tabular}

This table report summary statistics of the variables used in the empirical analysis for the Full Sample (Panel A) and the Balanced Sample (Panel B). The last two columns report the mean for country pairs conditional on joint EU membership. 
Pairwise Segmentation (SEG)

\author{
EU and Euro Indicators \\ EU - Indicator \\ Euro - Indicator \\ Exchange Rate Volatility Indicator
}

Distance to Brussels (in $1000 \mathrm{~km}$ )

Measure induced Controls Sum of number of listed firms (In)

Abs. Diff. in Leverage

Abs. Diff. in Ln Earnings Growth Volatility

Abs. Diff. in Return Volatility
Average of the absolute difference between industry earnings yields in country $A$ and country $B$, weighted by the sum of the industry market capitalization in country A and country B. Source: Datastream.

Indicator equals one if both countries are members of the EU in a given year.

Indicator equals one if both countries in a country-pair are part of the Euro area in a given year. Zero of all country-pairs before 1999.

Using daily exchange rates for the Deutsche Mark until 1998 and for the Euro afterwards, we compute a measure of the realized exchange rate volatility, $\sigma$ (the square root of the sum of squared daily exchange rate changes during a year) for all countries and years (with the exception of Russin in 1997). We transform the realized volatility onto a $[0,1]$ scale by computing $1 / \exp (1200 \sigma)$. Thus, a country with zero exchange rate volatility takes on a value of one; a country with $1 \%$ monthly volatility (roughly that of a major floating currency) would effectively receive a zero. For a country-pair, we employ the average value of the two countries in a pair.

For the most important city/agglomeration (as of 2004) in every country in our data set, we obtain the distance (in thousand of kilometers) to Brussels. With the exception of Germany, the most important city is the capital city. For a country-pair, we use the maximum of the two distances as our country. pair measure of distance to Brussels. Source: CEPII.

Natural log of the total number of listed firms in A and B used in construction of the bilateral segmentation measure. Source: Datastream.

We obtain annual accounting data for all public firms contained in Bureau van Dijk's OSIRIS data base. For industrial firms, we define financial leverage as the ratio of long term interest bearing debt to total assets. For financial firms, we define financial leverage as the ratio of total liabilities to total assets. Weighting each observation by total assets, we aggregate this ratio across all firms per industry, country and year. Since coverage is limited in time and across industries and countries, we use linear regressions based on country dummies, industry dummies, private credit over GDP as well as industry return volatility to predict industry leverage when leverage data are not available. We then take the absolute difference between industry leverage in country A and country B. Finally, for each country-pair and year we average this absolute leverge difference across all industries using the sum of an industry's market values in both countries as the weight.

We measure industry log earnings growth volatility by calculating the fiveyear standard deviation of quarterly log growth rates of 12-month earnings (measured in USD) for all industries in a given country. We require at least eight quarters of data for the calculation. We then form the weighted average of the absolute difference between the industry log earnings growth volatility in country $A$ and country $B$, where we use industry market values as weights.

We measure industry log return volatility by calculating the five-year standard deviation of monthly industry log returns (measured in USD) for all industries in a given country. We require at least 24 months of data for the calculation. We then form the weighted average of the absolute difference between the industry return volatility in country $A$ and country $B$, where we use industry market values as weights. 


\section{Similiarity and Proximity (time-invariant)}

Abs. Diff. in PC GDP in 1990 (in 1,000 USD)

Distance (in 1,000 km)

Common Language Indicator

Eastern Europe Indicator

Time-Series Controls

Abs. EY - Differential: Core Europe vs. USA

Core Europe - Earnings Yield

Potential Channels of Integration Trade

FDI

Capital Account Openness: Average

Capital Account Openness: Difference

Equity Market Openness: Average

Equity Market Openness: Difference

Financial Reform: Average

Financial Reform: Difference

MCAP/GDP: Average

MCAP/GDP: Difference
The absolute difference in per capita GDP (measured in constant USD) between two countries in a country-pair in 1990.

Distance between the most important cities/agglomerations (in terms of population) in thousands of kilometers. Source: CEPII.

Indicator equals one if the two countries in a country-pair share a common official language. Source: CEPII.

Indicator equals one if at least one of the two countries in a country-pair is an Eastern European country. See Appendix Table 1 for a list of Eastern European countries.

The average absolute difference between industry earning yields in Core Europe and the US. We obtain earnings yields for Core Europe by aggregating all industries across Core European countries. See Appendix Table1 for a list of Core European countries. Source: Datastream

The earning yield in Core Europe. We obtain earnings yields for Core Europe by aggregating all Core European countries. See Appendix Table1 for a list of Core European countries. Source: Datastream

Total of exports and imports between two countries in a country-pair, scaled by average GDP. Source: Datastream and WDI

Total of FDI holdings of country one in country tow plus those of country two in country one scaled by average GDP. Source: Eurostat and WDI

The average level of captial account regulation across the two countries in a country-pair. The variable takes on values between zero (closed) and three (fully liberalized). Source: IMF

The absolute difference in the level of capital account regulation between the two countries in a country-pair. Source: IMF

The average of measured equity market openness across the two countries in a country-pair. Equity market openness is measured as the ratio of the market capitalization of the constituent firms comprising Standard \& Poor's IFC Investable index to those that comprise Standard \& Poor's IFC Global index for each country. The IFC Global index, subject to some exclusion restrictions, is designed to represent the overall market portfolio for each country, whereas the IFC Investable index is designed to represent a portfolio of domestic equities that are available to foreign investors. A ratio of one means that all of the stocks are available to foreign investors. Fully segmented countries have an intensity measure of zero, and fully liberalized countries have an intensity measure of one.

The absolute difference in equity market openness between the two countries in a country-pair.

The average of the financial refrom index across the two countries in a country-pair. The index takes on values between zero (fully repressed) and 21 (fully liberalized). Source: IMF

The absolute difference in the financial refrom index between the two countries in a country-pair. Source: IMF

The average ratio of equity market capitalization to GDP across the two countries in a country-pair. Source: WDI

The absolute difference in the "equity market capitalization to GDP" ratio between the two countries in a country-pair. Source: WDI 
Absolute Real Interest Differential

Telecommunication: Average

Telecommunication: Difference

Foreign Residents
The absolute difference between the real interest rate in the two countries in a country pair. The real interest rate is measured as the prime rate less inflation as measured by the GDP deflator. Source: WDI

The average of the ratio "number of fixed lines and mobile phone subscribers per 100 people" across the two countries in a country-pair. Source: WDI

The absolute difference in the ratio "number of fixed lines and mobile phone subscribers per 100 people" between the two countries in a countrypair. Source: WDI

The ratio of the sum of citizens of country one living in country two and citizens of country two living in country one over the average of the population of country one and country two. Source: Eurorstat

This table defines all variables used in the empirical analysis. CEPII refers to the Centre d'Etudes Prospectives et d'Informations Internationales (www.cepii.eu). WDI is the World Development Indicators database maintained by the World Bank (www.worldbank.org). IMF is the International Monetary Fund (www.imf.org). 
Online Appendix Table

\section{List of Industries}

Industry Name

Oil \& Gas Producers

Oil Equipment \& Services

Alternative Energy

Chemicals

Forestry \& Paper

Industrial Metals \& Mining

Mining

Construction \& Materials

Aerospace \& Defense

General Industrials

Electronic \& Electrical Equipment

Industrial Engineering

Industrial Transportation

Support Services

Automobiles \& Parts

Beverages

Food Producers

Household Goods \& Home Construction

Leisure Goods

Personal Goods

Tobacco

Health Care Equipment \& Services

Pharmaceuticals \& Biotechnology

Food \& Drug Retailers

General Retailers

Media

Travel \& Leisure

Fixed Line Telecommunications

Mobile Telecommunications

Electricity

Gas, Water \& Multiutilities

Banks

Nonlife Insurance

Life Insurance

Real Estate Investment \& Services

Financial Services

Software \& Computer Services

Technology Hardware \& Equipment

This table lists the 38 industries that are used the construction of the bilateral segmentation measure. The industry classification follows the Industry Classification Benchmark (ICB), as adopted by DataStream. 
Online Appendix Table

System of Three Equations

Balanced Sample: 1990 - 2007 ( $N=$ 57,323; Monthly Frequency)

\begin{tabular}{|c|c|c|c|}
\hline & $\begin{array}{l}\text { Discount } \\
\text { Rates }\end{array}$ & $\begin{array}{c}\text { Expected } \\
\text { Earnings } \\
\text { Growth }\end{array}$ & Earnings Yields \\
\hline Intercept & $\begin{array}{l}\mathbf{0 . 2 5 5 8} \\
(0.0452)\end{array}$ & $\begin{array}{l}\mathbf{0 . 5 7 5 3} \\
(0.0389)\end{array}$ & $\begin{array}{l}0.0845 \\
(0.0845)\end{array}$ \\
\hline Predicted Return & & & $\begin{array}{l}\mathbf{0 . 0 3 4 4} \\
(0.0071)\end{array}$ \\
\hline Predicted Earnings Growth Rate & & & $\begin{array}{c}-\mathbf{0 . 1 3 4 8} \\
(0.0094)\end{array}$ \\
\hline EU - Indicator & $\begin{array}{c}-0.1549 \\
(0.0429)\end{array}$ & $\begin{array}{c}-0.0226 \\
(0.0264)\end{array}$ & \\
\hline DY - local (industry level) & $\begin{array}{l}\mathbf{0 . 8 9 9 5} \\
(0.2212)\end{array}$ & $\begin{array}{c}\mathbf{- 2 . 6 9 3 7} \\
(0.2782)\end{array}$ & \\
\hline DY - World (industry-level) & $\begin{array}{l}1.0737 \\
(0.5833)\end{array}$ & $\begin{array}{l}1.7014 \\
(0.5463)\end{array}$ & \\
\hline DY - Core Europe (industry-level) & $\begin{array}{l}-0.4207 \\
(1.0105)\end{array}$ & $\begin{array}{c}-4.0941 \\
(0.5405)\end{array}$ & \\
\hline Short term (1 year) US Treasury Yield in (\%) & $\begin{array}{c}-0.0492 \\
(0.0067)\end{array}$ & $\begin{array}{c}-0.0098 \\
(0.0036)\end{array}$ & \\
\hline Short term Govt. Yield (in \%) & $\begin{array}{c}-0.0106 \\
(0.0017)\end{array}$ & $\begin{array}{c}-\mathbf{0 . 0 1 6 3} \\
(0.0017)\end{array}$ & \\
\hline Default Spread - USA (in \%) & $\begin{array}{l}\mathbf{0 . 0 4 1 7} \\
(0.0181)\end{array}$ & $\begin{array}{c}-0.1233 \\
(0.0257)\end{array}$ & \\
\hline Term Spread - USA (in \%) & $\begin{array}{l}\mathbf{0 . 0 1 9 2} \\
(0.0055)\end{array}$ & $\begin{array}{l}0.0060 \\
(0.0048)\end{array}$ & \\
\hline IP Growth - local (country level, Y-o-Y) & $\begin{array}{c}-0.9504 \\
(0.2109)\end{array}$ & $\begin{array}{l}0.0559 \\
(0.1611)\end{array}$ & \\
\hline IP Growth - USA (country level, Y-o-Y) & $\begin{array}{l}3.2545 \\
(0.3715)\end{array}$ & & \\
\hline Earnings Growth (USD) - local (industry-leve, Y-o-Y) & $\begin{array}{l}\mathbf{0 . 0 5 4 0} \\
(0.0126)\end{array}$ & $\begin{array}{c}-\mathbf{0 . 0 8 6 4} \\
(0.0072)\end{array}$ & \\
\hline EU x DY - Core Europe (industry-level) & $\begin{array}{l}2.6802 \\
(1.0081)\end{array}$ & & \\
\hline EU x Short term (1 year) US Treasury Yield in (\%) & $\begin{array}{l}\mathbf{0 . 0 1 8 4} \\
(0.0061)\end{array}$ & & \\
\hline EU x Default Spread - USA (in \%) & & $\begin{array}{l}0.0272 \\
(0.0268)\end{array}$ & \\
\hline EU x IP Growth - local (country level, Y-o-Y) & $\begin{array}{l}\mathbf{0 . 7 9 0 4} \\
(0.2270)\end{array}$ & $\begin{array}{l}0.0870 \\
(0.1755)\end{array}$ & \\
\hline EU x IP Growth - USA (country level, Y-o-Y) & $\begin{array}{c}-\mathbf{- 1 . 3 3 5 1} \\
(0.3830)\end{array}$ & & \\
\hline EU x Earnings Growth (USD) - local (industry-leve, Y-o-Y) & $\begin{array}{c}-0.0337 \\
(0.0141)\end{array}$ & & \\
\hline$R^{2}$ & & & 0.174 \\
\hline
\end{tabular}

This table reports results from 2-step GMM estimation of a system of three equations: Annual country industry returns and earnings growth rates are modeled as a function of lagged (1-year) industry- and country level as well as international predictors, while industry earnings yields are modeled as a function of predicted contemporaneous annual returns and earnings growth rates. All data are employed at the monthly frequency. Included country industry portfolios are those used in the construction of the segmentation measure for the balanced sample (subject to data availability). Standard errors are robust to heteroskedasiticty and auto correlation of up to 20 months. Coefficient estimates with absolute $t$-statistics larger than 1.96 appear in bold. $N$ denotes the number of observations. Industry returns and earnings growth rates (measured in USD) as well as industry earnings yields are from main data set, which is obtained from DataStream. Industry dividend yields are obtained from Datastream. The U.S. Treasury yield, the U.S. default spread, and the U.S. terms spread are from Federal Reserve Economic Data (FRED). Short term government yields are from Global Financial Data. Industrial production (IP) growth rates are obtained from the International Financial Statistics (IFS) database. The $R^{2}$ is the amount of variation in the industry earnings yield explained by the estimated linear combination of predicted returns and earnings growth rates. 